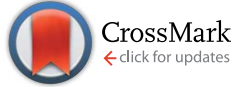

Cite this: RSC Adv., 2016, 6, 15370

Received 21st December 2015 Accepted 27th January 2016

DOI: 10.1039/c5ra27397h

www.rsc.org/advances

\title{
Improved light absorbance does not lead to better DSC performance: studies on a ruthenium porphyrin-terpyridine conjugate $\uparrow$
}

\author{
Angelo Lanzilotto, ${ }^{a}$ Laura A. Büldt, ${ }^{b}$ Hauke C. Schmidt, ${ }^{b}$ Alessandro Prescimone, ${ }^{a}$ \\ Oliver S. Wenger, ${ }^{b}$ Edwin C. Constable ${ }^{a}$ and Catherine E. Housecroft ${ }^{\star a}$
}

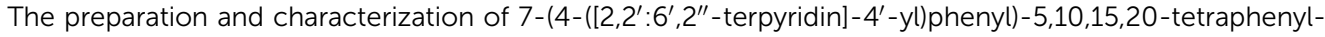
porphyrinatozinc(॥), 3, are reported, and the structure of 3 has been confirmed by a single crystal structure determination. Reaction of $\mathrm{RuCl}_{3} \cdot 3 \mathrm{H}_{2} \mathrm{O}$ with diethyl $\left(4-\left(\left[2,2^{\prime}: 6^{\prime}, 2^{\prime \prime}\right.\right.\right.$-terpyridin $]-4^{\prime}$-yl)phenyl) phosphonate, 4 , followed by 3 in reducing conditions gives $[R u(3)(4)]\left[P F_{6}\right]_{2}$. In solution, 3 and $[R u(3)(4)]$ $\left[\mathrm{PF}_{6}\right]_{2}$ undergo two, reversible porphyrin-centred oxidation processes at lower potential than the $\mathrm{Ru}^{2+} /$ $\mathrm{Ru}^{3+}$ process in $[\mathrm{Ru}(3)(4)]\left[\mathrm{PF}_{6}\right]_{2}$. In the solution absorption spectra, the Soret and $\mathrm{Q}$ bands in 3 are little perturbed upon complex formation; the MLCT band in $[R u(3)(4)]\left[P F_{6}\right]_{2}$ has $\lambda_{\max }=492 \mathrm{~nm}$. Spectroelectrochemical data for 3 and $[R u(3)(4)]\left[\mathrm{PF}_{6}\right]_{2}$ are presented. $[\mathrm{Ru}(3)(4)]^{2+}$ binds to nanoparticulate $\mathrm{TiO}_{2}$ and the solid-state absorption spectrum confirms enhanced light absorption with respect to the standard dye-sensitized solar cell (DSC) dye N719. However, the photoconversion efficiencies of DSCs sensitized with $[\mathrm{Ru}(3)(4)]^{2+}$ are disappointingly low. Transient absorption spectroscopic studies on this series of compounds indicate that triplet-triplet energy transfer processes are likely to be responsible for this poor performance.
\end{abstract}

\section{Introduction}

Ever since the first development of Grätzel n-type dye-sensitized solar cells (DSCs) employing sintered semiconductor nanoparticles functionalized with ruthenium(II)-based dyes, ${ }^{1-3}$ efforts have been concentrated on the improvement of the photoconversion efficiency. At present, state-of-the-art photoconversion efficiencies approach $\sim 13 \%$ in DSCs using ruthenium(II)-based, metal-free organic and zinc(II) porphyrinbased dyes. ${ }^{\mathbf{4 - 1 6}}$ Nature's reliance on porphyrins in photosystem II has lead to significant interest in bioinspired devices utilizing porphyrin or metalloporphyrin-based sensitizers in DSCs, ${ }^{4,17-19}$ and a power conversion efficiency of $13 \%$ has been reported by Grätzel and coworkers for a porphyrin dye incorporating a donor- $\pi$-bridge-acceptor domain combined with a cobalt(II)/(III)redox shuttle. ${ }^{14}$

While both ruthenium- and porphyrin-based sensitizers are popular choices in DSCs, to the best of our knowledge, few

${ }^{a}$ Department of Chemistry, University of Basel, Spitalstrasse 51, CH-4056 Basel, Switzerland. E-mail: catherine.housecroft@unibas.ch

${ }^{b}$ Department of Chemistry, University of Basel, St. Johanns-Ring 19, CH-4056 Basel, Switzerland

$\dagger$ Electronic supplementary information (ESI) available: Fig. S1 and S2: HMQC and HMBC spectra of 3; Fig. S3 and S4: additional $\mathrm{CV}$ and spectroelectrochemical data for 3. CCDC 1442417. For ESI and crystallographic data in CIF or other electronic format see DOI: $10.1039 / \mathrm{c} 5 \mathrm{ra} 27397 \mathrm{~h}$ sensitizers have combined polypyridylruthenium(II) and porphyrin domains in a single molecular species. ${ }^{\text {20-22 }}$ Our approach to ruthenium(II) dyes containing light-harvesting porphyrin domains is predicated upon heteroleptic $\left\{\mathrm{Ru}^{\mathrm{II}}(\mathrm{tpy})_{2}\right\}$ domains in which the two tpy ligands bear anchoring and porphyrin substituents, respectively. The majority of oligopyridine-porphyrin conjugates are characterized by the attachment of the metal-binding domains directly or with a spacer to the phenyl-substituents of 5,10,15,20-tetraphenyl-21H,23H-porphyrins. ${ }^{23}$

We have now developed new approaches for the functionalization of porphyrins in which oligopyridines and their metal complexes are attached directly to a pyrrole ring of the porphyrin core. The selective monobromination of $\mathrm{H}_{2} \mathrm{TPP}$ in the 7-position developed by Zhang and coworkers, ${ }^{24}$ provided an attractive opening for our synthetic investigations into monofunctionalization of a porphyrin core with a $2,2^{\prime}: 6^{\prime}, 2^{\prime \prime}$-terpyridine (tpy) domain.

\section{Experimental}

\section{General}

Microwave reactions were carried out in a Biotage Initiator 8 reactor. ${ }^{1} \mathrm{H},{ }^{13} \mathrm{C}$ and ${ }^{31} \mathrm{P}$ NMR spectra were recorded at room temperature using a Bruker Avance III-500 NMR spectrometer. ${ }^{1} \mathrm{H}$ and ${ }^{13} \mathrm{C}$ NMR chemical shifts were referenced to residual solvent peaks with respect to $\delta(\mathrm{TMS})=0 \mathrm{ppm}$ and ${ }^{31} \mathrm{P} \mathrm{NMR}$ 
chemical shifts with respect to $\delta\left(85 \%\right.$ aqueous $\left.\mathrm{H}_{3} \mathrm{PO}_{4}\right)=0 \mathrm{ppm}$. Solution absorption and emission spectra were measured using an Agilent 8453 spectrophotometer and a Shimadzu RF-5301PC spectrofluorometer, respectively. Spectroelectrochemical and solid-state absorption spectroscopic measurements used a Varian-Cary 5000 spectrophotometer. Electrospray (ESI) mass spectra and high resolution ESI-MS were measured on Bruker Esquire $3000^{\text {plus }}$ and Bruker maXis $4 \mathrm{G}$ instruments, respectively. Nanosecond transient absorption spectra were measured on an LP-920KS spectrometer from Edinburgh Instruments using a frequency-doubled Quantel Brilliant B laser as a pump source. Transient absorption measurements with picosecond time resolution were performed with the TRASS instrument from Hamamatsu, equipped with a C7701-01 streak camera. Excitation occurred with a picosecond mode-locked $\mathrm{Nd}: \mathrm{YVO}_{4} /$ YAG laser (PL2251B-20-SH/TH/FH) with PRETRIG option from Ekspla.

Electrochemical measurements were carried out using a $\mathrm{CH}$ Instruments 900B potentiostat with $\left[{ }^{n} \mathrm{Bu}_{4} \mathrm{~N}\right]\left[\mathrm{PF}_{6}\right](0.1 \mathrm{M})$ as supporting electrolyte and at a scan rate of $0.1 \mathrm{~V} \mathrm{~s}^{-1}$. The working electrode was glassy carbon, pseudo-reference electrode silver wire and counter-electrode platinum wire; potentials were referenced with respect to the $\mathrm{Fc} / \mathrm{Fc}^{+}$couple. Spectroelectrochemical measurements were performed using a $\mathrm{CH}_{2} \mathrm{Cl}_{2}$ solution of $3(1 \mathrm{mM})$ and an $\mathrm{MeCN}$ solution of $[\mathrm{Ru}(3)(4)]\left[\mathrm{PF}_{6}\right]_{2}(0.6 \mathrm{mM})$ at room temperature with $\left[{ }^{n} \mathrm{Bu}_{4} \mathrm{~N}\right]\left[\mathrm{PF}_{6}\right]$ $(\approx 0.1 \mathrm{M})$ as the supporting electrolyte. The solution was added to an optically transparent thin-layer electrochemical (OTTLE) cell with two Pt minigrid electrodes (working and auxiliary), a silver wire pseudoreference electrode, and a path length of $\approx 0.2 \mathrm{~mm}$. The potential was controlled using a VersaSTAT 3 potentiostat from Princeton Applied Research.

$\mathrm{RuCl}_{3} \cdot 3 \mathrm{H}_{2} \mathrm{O}$ was purchased from Oxkem, and 5,10,15,20tetraphenyl-21H,23H-porphyrin $\left(\mathrm{H}_{2} \mathrm{TPP}\right), \mathrm{NBS}$ and $\left[\mathrm{Pd}\left(\mathrm{PPh}_{3}\right)_{4}\right]$ from Sigma-Aldrich and used as received. 7-Bromo-5,10,15,20tetraphenyl-21H,23H-porphyrin, ${ }^{24} \mathbf{1},{ }^{25} 2$ (ref. 26) and 4 (ref. 27) were prepared as previously reported and spectroscopic data matched those in the literature.

\section{Compound 3}

Compound 1 (100 mg, $0.13 \mathrm{mmol}, 1$ eq.), $\mathrm{K}_{2} \mathrm{CO}_{3}$ (72 mg, $0.52 \mathrm{mmol}, 4$ eq.) and 2 (53 mg, $0.15 \mathrm{mmol}, 1.2$ eq.) were combined in a $20 \mathrm{~mL}$ microwave vial and dissolved in a mixture of toluene $(9.5 \mathrm{~mL})$ and deionized water $(0.6 \mathrm{~mL}) . \mathrm{N}_{2}$ was bubbled through the solution for $30 \mathrm{~min}$ and then $\left[\mathrm{Pd}\left(\mathrm{PPh}_{3}\right)_{4}\right]$ (15 mg, $0.013 \mathrm{mmol}, 0.1 \mathrm{eq}$.) was added and the vial sealed. The reaction mixture was heated for $4 \mathrm{~h}$ at $120{ }^{\circ} \mathrm{C}$ in a microwave reactor, after which time the solvent was removed under reduced pressure. Column chromatography $\left(\mathrm{SiO}_{2}, \mathrm{CHCl}_{3}\right)$ was performed on the crude material. The fraction containing [Zn(TPP)] eluted first and compound 2 was collected as the second (dark red-purple) fraction $\left(R_{\mathrm{f}}=0.1\right) .3$ was isolated as a dark purple solid (89 mg, $0.090 \mathrm{mmol}, 69 \%) .{ }^{1} \mathrm{H}$ NMR (500 $\left.\mathrm{MHz} \mathrm{CDCl}_{3}\right) \delta / \mathrm{ppm} 8.95-8.99\left(\mathrm{~m}, 2 \mathrm{H}, \mathrm{H}^{\mathrm{F} 3+\mathrm{F} 4 / \mathrm{F}^{\prime}+\mathrm{F}^{\prime}}\right), 8.96(\mathrm{~s}, 1 \mathrm{H}$, $\left.\mathrm{H}^{\mathrm{H} 3}\right), 8.95\left(\mathrm{~s}, 2 \mathrm{H}, \mathrm{H}^{\mathrm{I} 3+\mathrm{I} 4}\right), 8.89\left(\mathrm{~d}, J=4.5 \mathrm{~Hz}, 2 \mathrm{H}, \mathrm{H}^{\mathrm{F} 3+\mathrm{F} 4 / \mathrm{F}^{\prime}+\mathrm{F}^{\prime}}\right)$, $8.84\left(\mathrm{~d}, J=4.5 \mathrm{~Hz}, 2 \mathrm{H}, \mathrm{H}^{\mathrm{F} 3 / \mathrm{F} 4 / \mathrm{F}^{\prime} / \mathrm{F} 4^{\prime}}\right), 8.79\left(\mathrm{~s}, 2 \mathrm{H}, \mathrm{H}^{\mathrm{B} 3}\right), 8.76$ (ddd,
$\left.J=4.7,1.8,0.9 \mathrm{~Hz}, 2 \mathrm{H}, \mathrm{H}^{\mathrm{A} 6}\right), 8.71\left(\mathrm{dt}, J=8.0,1.1 \mathrm{~Hz}, 2 \mathrm{H}, \mathrm{H}^{\mathrm{A} 3}\right)$, 8.28-8.23 (m, 6H, $\left.\mathrm{H}^{\mathrm{E} 2+\mathrm{G} 2}\right), 7.93-7.88\left(\mathrm{~m}, 4 \mathrm{H}, \mathrm{H}^{\mathrm{A} 4+\mathrm{D} 2}\right), 7.79-7.71$ $\left(\mathrm{m}, 11 \mathrm{H}, \mathrm{H}^{\mathrm{E} 3+\mathrm{E} 4+\mathrm{G} 3+\mathrm{G} 4+\mathrm{C} 2}\right), 7.50\left(\mathrm{~m}, 2 \mathrm{H}, \mathrm{H}^{\mathrm{C} 3}\right), 7.37\left(\mathrm{~m}, 2 \mathrm{H}, \mathrm{H}^{\mathrm{A} 5}\right)$, 7.23-7.29 (m, 3H, $\left.\mathrm{H}^{\mathrm{D} 3+\mathrm{D} 4}\right) .{ }^{13} \mathrm{C}$ NMR $\left(126 \mathrm{MHz}, \mathrm{CDCl}_{3}\right) \delta / \mathrm{ppm}$ $156.6\left(\mathrm{C}^{\mathrm{A} 2 / \mathrm{B} 2}\right), 156.1\left(\mathrm{C}^{\mathrm{A} 2 / \mathrm{B} 2}\right), 151.4\left(\mathrm{C}^{\mathrm{Q}}\right), 150.7\left(\mathrm{C}^{\mathrm{Q}}\right), 150.49\left(\mathrm{C}^{\mathrm{Q}}\right)$, $150.47\left(\mathrm{C}^{\mathrm{Q}}\right), 150.43\left(\mathrm{C}^{\mathrm{Q}}\right), 150.42\left(\mathrm{C}^{\mathrm{Q}}\right), 150.4\left(\mathrm{C}^{\mathrm{B} 4}\right), 149.3\left(\mathrm{C}^{\mathrm{A} 6}\right)$, $148.0\left(\mathrm{C}^{\mathrm{Q}}\right), 146.85\left(\mathrm{C}^{\mathrm{Q}}\right), 146.8\left(\mathrm{C}^{\mathrm{Q}}\right), 143.0\left(\mathrm{C}^{\mathrm{Q}}\right), 142.91\left(\mathrm{C}^{\mathrm{Q}}\right)$, $142.89\left(\mathrm{C}^{\mathrm{Q}}\right), 141.5\left(\mathrm{C}^{\mathrm{Q}}\right), 140.8\left(\mathrm{C}^{\mathrm{Q}}\right), 137.0\left(\mathrm{C}^{\mathrm{D} 2 / \mathrm{A} 4}\right), 135.8\left(\mathrm{C}^{\mathrm{D} 2 / \mathrm{A} 4}\right)$, $135.4 \quad\left(\mathrm{C}^{\mathrm{H} 3 / \mathrm{Q}}\right), \quad 135.35 \quad\left(\mathrm{C}^{\mathrm{H} 3 / \mathrm{Q}}\right), \quad 134.6 \quad\left(\mathrm{C}^{\mathrm{E} 2 / \mathrm{G} 2}\right), \quad 134.55$ $\left(\mathrm{C}^{\mathrm{E} 2 / \mathrm{G} 2}\right), 132.9\left(\mathrm{C}^{\mathrm{F} 3 / \mathrm{F} 4 / \mathrm{F} 3^{\prime} / \mathrm{F} 4^{\prime} / \mathrm{I} 3 / \mathrm{I} 4}\right), 132.3\left(\mathrm{C}^{\mathrm{F} 3 / \mathrm{F} 4 / \mathrm{F} 3^{\prime} / \mathrm{F} 4^{\prime} / \mathrm{I} 3 / \mathrm{I} 4}\right), 132.25$ $\left(\mathrm{C}^{\mathrm{F} 3 / \mathrm{F} 4 / \mathrm{F}^{\prime} / \mathrm{F} 4^{\prime} / \mathrm{I} 3 / \mathrm{I} 4}\right), 132.2\left(\mathrm{C}^{\mathrm{F} 3 / \mathrm{F} 4 / \mathrm{F}^{\prime} / \mathrm{F}^{\prime} / \mathrm{I3} / \mathrm{I} 4}\right), 132.1\left(\mathrm{C}^{\mathrm{F} 3 / \mathrm{F} 4 / \mathrm{F3}^{\prime} / \mathrm{F}^{\prime} / \mathrm{I3} / \mathbf{I} 4}\right)$, $131.6\left(\mathrm{C}^{\mathrm{F} 3 / \mathrm{F} 4 / \mathrm{F}^{\prime} / \mathrm{F} 4^{\prime} / \mathrm{I} 3 / \mathrm{I} 4}\right), 131.0\left(\mathrm{C}^{\mathrm{C} 3}\right), 127.7\left(\mathrm{C}^{\mathrm{E} 3 / \mathrm{E} 4 / \mathrm{G} 3 / \mathrm{G} 4}\right), 127.65$ $\left(\mathrm{C}^{\mathrm{E} 3 / \mathrm{E} 4 / \mathrm{G} 3 / \mathrm{G} 4}\right), 127.3\left(\mathrm{C}^{\mathrm{D} 4}\right), 126.8\left(\mathrm{C}^{\mathrm{E} 3 / \mathrm{E} 4 / \mathrm{G} 3 / \mathrm{G} 4}\right), 126.2\left(\mathrm{C}^{\mathrm{D} 3+\mathrm{C} 2}\right)$, $123.9\left(\mathrm{C}^{\mathrm{A} 5}\right), 122.6,121.7\left(\mathrm{C}^{\mathrm{Q}}\right), 121.6\left(\mathrm{C}^{\mathrm{A} 3}\right), 121.2\left(\mathrm{C}^{\mathrm{Q}}\right), 120.8\left(\mathrm{C}^{\mathrm{Q}}\right)$, $118.8\left(\mathrm{C}^{\mathrm{B} 3}\right)\left(\mathrm{C}^{\mathrm{Q}}=\right.$ quaternary $\mathrm{C}$, not unambiguously assigned). ESI MS $m / z$ (positive mode) $984.7[\mathrm{M}+\mathrm{H}]^{+}$(calc. 984.3). UV-Vis $\left(\mathrm{EtOH}, 9.7 \times 10^{-7} \mathrm{~mol} \mathrm{dm}{ }^{-3}\right) \lambda / \mathrm{nm}\left(\varepsilon / \mathrm{dm}^{3} \mathrm{~mol}^{-1} \mathrm{~cm}^{-1}\right) 285$ (56 000), 315 (41 000), 427 (520 000), 560 (26 000), 599 (9500). Found C 75.89, H 4.41, N 9.49; $\mathrm{C}_{65} \mathrm{H}_{41} \mathrm{~N}_{7} \mathrm{Zn} \cdot 3 \mathrm{H}_{2} \mathrm{O}: \mathrm{C} 75.10, \mathrm{H}$ 4.56, N 9.43 .

\section{$\left[\mathrm{Ru}(4) \mathrm{Cl}_{3}\right]$}

Compound 4 (27 mg, $0.061 \mathrm{mmol}, 1$ eq.) and $\mathrm{RuCl}_{3} \cdot 3 \mathrm{H}_{2} \mathrm{O}$ (16 mg, $0.061 \mathrm{mmol}, 1$ eq.) were suspended in EtOH $(10 \mathrm{~mL})$ and heated at reflux for $3.5 \mathrm{~h}$. A brown precipitate formed, which was centrifuged, then washed with $\mathrm{EtOH}$ and $\mathrm{Et}_{2} \mathrm{O}$. Brown $\left[\mathrm{Ru}(4) \mathrm{Cl}_{3}\right]$ (28 mg, $\left.0.043 \mathrm{mmol}, 70 \%\right)$ was used for the next step without further characterization.

\section{$[\mathrm{Ru}(3)(4)]\left[\mathrm{PF}_{6}\right]_{2}$}

$\left[\mathrm{Ru}(4) \mathrm{Cl}_{3}\right]$ (28 mg, $0.043 \mathrm{mmol}, 1$ eq.), 3 (42.4 mg, $0.043 \mathrm{mmol}$, 1 eq.) and $N$-ethylmorpholine ( 2 drops) were suspended in dry EtOH $(2 \mathrm{~mL})$ in a microwave reactor vial. The mixture was heated in a microwave reactor at $140{ }^{\circ} \mathrm{C}$ for $20 \mathrm{~min}$ and then the dark red solution was poured into saturated aqueous $\mathrm{NH}_{4} \mathrm{PF}_{6}$ $(50 \mathrm{~mL})$. The precipitate that formed was centrifuged down, collected and washed with water and $\mathrm{Et}_{2} \mathrm{O}(3 \times 5 \mathrm{~mL})$. The residue was dissolved in MeCN and purified by column chromatography $\left(\mathrm{SiO}_{2}, \mathrm{MeCN} /\right.$ saturated aq. $\mathrm{KNO}_{3} /$ water $7: 1: 0.5$ by volume). The first orange fraction $\left(R_{\mathrm{f}}=0.67\right)$ was collected, then concentrated to $3 \mathrm{~mL}$ and poured in saturated aqueous $\mathrm{NH}_{4} \mathrm{PF}_{6}$ $(25 \mathrm{~mL})$ to give a precipitate which was washed with water and EtOH $(3 \times 5 \mathrm{~mL})$. $[\mathrm{Ru}(3)(4)]\left[\mathrm{PF}_{6}\right]_{2}$ was isolated as a purple powder (20 mg, $0.011 \mathrm{mmol}, 26 \%) .{ }^{1} \mathrm{H}$ NMR (500 MHz, $\left.\mathrm{CD}_{3} \mathrm{CN}\right) \delta / \mathrm{ppm}$ $9.06\left(\mathrm{~s}, 2 \mathrm{H}, \mathrm{H}^{\mathrm{B} 3^{\prime \prime}}\right), 9.01\left(\mathrm{~s}, 2 \mathrm{H}, \mathrm{H}^{\mathrm{B} 3}\right), 8.89\left(\mathrm{~m}, 2 \mathrm{H}, \mathrm{H}^{\mathrm{F} 3+\mathrm{F} 4 / \mathrm{F}^{\prime}+\mathrm{F}^{\prime}}\right)$, $8.86\left(\mathrm{~s}, 1 \mathrm{H}, \mathrm{H}^{\mathrm{H} 3}\right), 8.85\left(\mathrm{~s}, 2 \mathrm{H}, \mathrm{H}^{\mathrm{I} 3+\mathrm{I} 4}\right), 8.82(\mathrm{~d}, J=4.5 \mathrm{~Hz}, 2 \mathrm{H}$, $\left.\mathrm{H}^{\mathrm{F} 3 / \mathrm{F} 4 / \mathrm{F}^{\prime} / \mathrm{F}^{\prime}}\right), 8.79\left(\mathrm{~d}, J=4.5 \mathrm{~Hz}, 2 \mathrm{H}, \mathrm{H}^{\mathrm{F} 3 / \mathrm{F} 4 / \mathrm{F3}^{\prime} / \mathrm{F}^{\prime}}\right), 8.75(\mathrm{~m}, 2 \mathrm{H}$, $\left.\mathrm{H}^{\mathrm{A} 3^{\prime \prime}}\right), 8.69\left(\mathrm{~m}, 2 \mathrm{H}, \mathrm{H}^{\mathrm{A} 3}\right), 8.33\left(\mathrm{~m}, 2 \mathrm{H}, \mathrm{H}^{\mathrm{C} 2^{\prime \prime}}\right), 8.30\left(\mathrm{~m}, 2 \mathrm{H}, \mathrm{H}^{\mathrm{G} 2}\right)$, $8.24\left(\mathrm{~m}, 4 \mathrm{H}, \mathrm{H}^{\mathrm{E} 2}\right), 8.09\left(\mathrm{~m}, 2 \mathrm{H}, \mathrm{H}^{\mathrm{C} 3}\right), 7.98-8.05(\mathrm{~m}, 6 \mathrm{H}$, $\mathrm{H}^{\mathrm{A} 4^{\prime \prime}+\mathrm{A} 4+\mathrm{D} 2}$ ), $7.95\left(\mathrm{~d}, J=8.5 \mathrm{~Hz}, 2 \mathrm{H}, \mathrm{H}^{\mathrm{C} 2}\right), 7.77-7.86(\mathrm{~m}, 9 \mathrm{H}$, $\left.\mathrm{H}^{\mathrm{E} 3+\mathrm{E} 4+\mathrm{G} 3+\mathrm{G} 4}\right), 7.70\left(\mathrm{~d}, J=8.5 \mathrm{~Hz}, 2 \mathrm{H}, \mathrm{H}^{\mathrm{C} 3}\right), 7.53\left(\mathrm{~m}, 2 \mathrm{H}, \mathrm{H}^{\mathrm{A} 6^{\prime \prime}}\right)$, $7.47\left(\mathrm{~m}, 2 \mathrm{H}, \mathrm{H}^{\mathrm{A} 6}\right), 7.43-7.46\left(\mathrm{~m}, 1 \mathrm{H}, \mathrm{H}^{\mathrm{D} 4}\right), 7.38\left(\mathrm{~m}, 2 \mathrm{H}, \mathrm{H}^{\mathrm{D} 3}\right), 7.27$ $\left(\mathrm{m}, 2 \mathrm{H}, \mathrm{H}^{\mathrm{A} 5}\right), 7.22\left(\mathrm{~m}, 2 \mathrm{H}, \mathrm{H}^{\mathrm{A} 5}\right), 4.14\left(\mathrm{~m}, 4 \mathrm{H}, \mathrm{H}^{\mathrm{Et}}\right), 1.35(\mathrm{t}, J=7$ $\left.\mathrm{Hz}, 6 \mathrm{H}, \mathrm{H}^{\mathrm{Et}}\right) .{ }^{13} \mathrm{C} \mathrm{NMR}\left(126 \mathrm{MHz}, \mathrm{CD}_{3} \mathrm{CN}\right) \delta / \mathrm{ppm} 159.3\left(\mathrm{C}^{\mathrm{A} 2^{\prime \prime} / \mathrm{B}^{\prime \prime}}\right)$, $159.0\left(\mathrm{C}^{\mathrm{A} 2 / \mathrm{B} 2}\right), 156.8\left(\mathrm{C}^{\mathrm{A} 2^{\prime \prime} / \mathrm{B} 2^{\prime \prime}}\right), 156.3\left(\mathrm{C}^{\mathrm{A} 2 / \mathrm{B} 2}\right), 153.4\left(\mathrm{C}^{\mathrm{A} 6+\mathrm{A} 6^{\prime \prime}}\right)$, $151.9\left(\mathrm{C}^{\mathrm{Q}}\right), 151.0\left(\mathrm{C}^{\mathrm{Q}}\right), 148.5\left(\mathrm{C}^{\mathrm{Q}}\right), 147.9\left(\mathrm{C}^{\mathrm{B} 4}\right), 147.1\left(\mathrm{C}^{\mathrm{B} 4^{\prime \prime}}\right), 147.0$ 
$\left(\mathrm{C}^{\mathrm{Q}}\right), 144.0\left(\mathrm{C}^{\mathrm{Q}}\right), 143.8\left(\mathrm{C}^{\mathrm{Q}}\right), 143.2\left(\mathrm{C}^{\mathrm{Q}}\right), 143.0\left(\mathrm{C}^{\mathrm{Q}}\right), 141.5\left(\mathrm{C}^{\mathrm{Q}}\right), 139.0$ $\left(\mathrm{C}^{\mathrm{A} 4+\mathrm{A} 4^{\prime \prime}}\right), 136.9\left(\mathrm{C}^{\mathrm{D} 2}\right), 135.7\left(\mathrm{C}^{\mathrm{H} 3}\right), 135.3\left(\mathrm{C}^{\mathrm{E} 2}\right), 135.2\left(\mathrm{C}^{\mathrm{G} 2}\right), 134.4$ $\left(\mathrm{C}^{\mathrm{Q}}\right), 133.4\left(\mathrm{C}^{\mathrm{C} 3^{\prime \prime}}\right), 133.1\left(\mathrm{C}^{\mathrm{F} 3 / \mathrm{F} 4 / \mathrm{F3}^{\prime} / \mathrm{F}^{\prime}}\right), 132.7\left(\mathrm{C}^{\mathrm{I} 3+\mathrm{I} 4+\text { two of } \mathrm{F} 3 / \mathrm{F} 4 / \mathrm{F3}^{\prime} / \mathrm{F}^{\prime}}\right)$, $132.2\left(\mathrm{H}^{\mathrm{F} 3 / \mathrm{F} 4 / \mathrm{F}^{\prime} / \mathrm{F}^{\prime}}\right), 132.1\left(\mathrm{C}^{\mathrm{C} 3}\right), 131.8\left(\mathrm{C}^{\mathrm{C} 4^{\prime \prime}}, J_{\mathrm{PC}}=189 \mathrm{~Hz}\right), 129.0$ $\left(\mathrm{C}^{\mathrm{C} 2^{\prime \prime}}\right), 128.5\left(\mathrm{H}^{\mathrm{A} 5+\mathrm{A} 5^{\prime \prime}}\right), 127.8\left(\mathrm{C}^{\mathrm{E} 3+\mathrm{E} 4+\mathrm{G} 3+\mathrm{G} 4+\mathrm{D} 4}\right), 127.4\left(\mathrm{C}^{\mathrm{C} 2}\right), 127.0$ $\left(\mathrm{C}^{\mathrm{D} 3}\right), 125.5\left(\mathrm{C}^{\mathrm{A} 3+\mathrm{A} 3^{\prime \prime}}\right), 123.0\left(\mathrm{C}^{\mathrm{B} 3^{\prime \prime}}\right), 122.2\left(\mathrm{C}^{\mathrm{B} 3}\right), 63.2\left(\mathrm{C}^{\mathrm{Et}}\right), 16.6\left(\mathrm{C}^{\mathrm{Et}}\right)$, $\left(\mathrm{C}^{\mathrm{Q}}=\right.$ quaternary $\mathrm{C}$, not all resolved). ESI MS $\mathrm{m} / \mathrm{z}$ (positive mode) $765.6[\mathrm{M}]^{2+}$ (calc. 765.7), negative mode $144.8\left[\mathrm{PF}_{6}\right]^{-}$(calc. 145.0). UV-Vis (MeCN, $\left.1 \times 10^{-6} \mathrm{~mol} \mathrm{dm}{ }^{-3}\right) \lambda / \mathrm{nm}\left(\varepsilon / \mathrm{dm}^{3} \mathrm{~mol}^{-1} \mathrm{~cm}^{-1}\right) 284$ (79 000), 312 (87 000), 425 (370 000), 492 (56 000), 559 (28 000), 599 (10 000). Found: C 57.38, $\mathrm{H} 4.07, \mathrm{~N}$ 8.01; $\mathrm{C}_{90} \mathrm{H}_{65} \mathrm{~F}_{12} \mathrm{~N}_{10} \mathrm{O}_{3} \mathrm{P}_{3^{-}}$ $\mathrm{RuZn} \cdot 2 \mathrm{H}_{2} \mathrm{O}$ requires C 58.18, H 3.74, N 7.54.

\section{Crystallography}

Data were collected on a Bruker Kappa Apex2 diffractometer with data reduction, solution and refinement using $\mathrm{APEX}^{28}$ and CRYSTALS. $^{29}$ The program Mercury v. $3.7^{\mathbf{3 0 , 3 1}}$ was used for structural analysis.

\section{Compound $3 \cdot \mathrm{Me}_{2} \mathrm{CO}$}

$\mathrm{C}_{68} \mathrm{H}_{47} \mathrm{~N}_{7} \mathrm{OZn}, M=1043.55$, red block, monoclinic, space group $P 2_{1} / c, a=13.1741(13), b=20.850(3), c=19.578(2) \AA, \beta=$ $102.558(6)^{\circ}, U=5249.2(10) \AA^{3}, Z=4, D_{\mathrm{c}}=1.320 \mathrm{Mg} \mathrm{m}^{-3}, \mu(\mathrm{Cu}-$ $\mathrm{K} \alpha)=1.063 \mathrm{~mm}^{-1}, T=123 \mathrm{~K}$. Total 66771 reflections, 9749 unique, $R_{\text {int }}=0.078$. Refinement of 7565 reflections (694 parameters) with $I>2 \sigma(I)$ converged at final $R_{1}=0.0894\left(R_{1}\right.$ all data $=0.2457), \mathrm{w} R_{2}=0.1059\left(\mathrm{w} R_{2}\right.$ all data $\left.=0.2583\right)$, gof $=$ 1.0000. CCDC 1442417.

\section{DSC fabrication}

Solaronix Test Cell Titania Electrodes were heated to $450{ }^{\circ} \mathrm{C}$ for $30 \mathrm{~min}$ and then cooled to $80{ }^{\circ} \mathrm{C}$, when they were dipped into the dye-baths. N719 (Solaronix) reference electrodes and electrodes with adsorbed $[\mathrm{Ru}(\mathbf{3})(\mathbf{4})]^{2+}$ were made by dipping in an EtOH solution of N719 $(0.1 \mathrm{mM})$ or MeCN solution of $[\mathrm{Ru}(3)(4)]$ $\left[\mathrm{PF}_{6}\right]_{2}(0.1 \mathrm{mM})$, respectively, for 3 days. The electrodes were taken out of the dye-baths, washed with EtOH or MeCN, respectively, and dried using a heatgun $\left(60{ }^{\circ} \mathrm{C}\right)$. Commercial counter electrodes (Solaronix Test Cell Platinum Electrodes) were washed with $\mathrm{EtOH}$, and then heated on a hot plate at $450{ }^{\circ} \mathrm{C}$ for $30 \mathrm{~min}$ to remove volatile organic impurities.

The working and counter-electrodes were joined using thermoplast hot-melt sealing foil (Solaronix Test Cell Gaskets, $60 \mu \mathrm{m}$ ) by heating while pressing together. The electrolyte (LiI (0.1 M), I 2 (0.05 M), 1-methylbenzimidazole (0.5 M), 1-butyl-3methylimidazolinium iodide $(0.6 \mathrm{M})$ in 3-methoxypropionitrile) was inserted between the electrodes by vacuum backfilling through a hole in the counter electrode; this was sealed (Solaronix Test Cell Sealings) and capped (Solaronix Test Cell Caps). All DSCs were fully masked for measurements. ${ }^{32,33}$

\section{Electrodes for solid-state absorption spectroscopy}

Dye-functionalized electrodes were assembled as above but using Solaronix Test Cell Titania Electrodes Transparent.

\section{DSC measurements}

Masks for the DSCs were made from a black-coloured copper sheet with an aperture of average area $0.06012 \mathrm{~cm}^{2}(1 \%$ standard deviation) placed over the active area of the DSC. The area of the mask hole was less than the surface area of $\mathrm{TiO}_{2}$ $\left(0.36 \mathrm{~cm}^{2}\right)$. Black tape was used to complete the masking of the cell. Performance measurements were made by irradiating the DSC from behind with a LOT Quantum Design LS0811 instrument (100 $\mathrm{mW} \mathrm{cm}^{-2}=1 \mathrm{sun}$ ), and the simulated light power was calibrated with a silicon reference cell.

\section{Results and discussion}

\section{Synthesis and characterization of compound 3}

The synthetic route to the porphyrin-functionalized $2,2^{\prime}: 6^{\prime}, 2^{\prime \prime}$ terpyridine 3 is summarized in Scheme 1 . The selective bromination of $\mathrm{H}_{2}$ TPP in the 7-position was carried out using NBS as described by Zhang and coworkers, ${ }^{24}$ and an excess of zinc(II) acetate $^{25}$ was added to yield zinc(II) complex 1 . When the metallation of $\mathrm{H}_{2}$ TPP with zinc(II) was carried out prior to reaction with NBS, selective halogenation was no longer observed and a mixture of brominated derivatives was obtained. The reaction of 1 with boronic acid $2^{26}$ under Suzuki-Miyaura cross-coupling conditions led to 3 in $69 \%$ yield after workup. Metallation of the porphyrin core before the coupling reaction is essential. Although 7-bromo-5,10,15,20-tetraphenyl-21 $\mathrm{H}, 23 \mathrm{H}$-porphyrin undergoes coupling with 2 to give the zinc-free analogue of 3 , subsequent reaction with $\mathrm{Zn}(\mathrm{OAc})_{2} \cdot 4 \mathrm{H}_{2} \mathrm{O}$ leads to competition between the porphyrin and tpy metal-binding domains for coordination to zinc(II). Thus, the sequence of steps presented in Scheme 1 is the optimal route to 3 .

The highest mass peak envelope in the electrospray mass spectrum of 3 came at $\mathrm{m} / \mathrm{z} 984.7$ and exhibited a characteristic isotope pattern for zinc. The ${ }^{1} \mathrm{H}$ NMR spectrum of 3 is shown in Fig. 1a and was assigned using COSY and NOESY methods. The spectrum is consistent with the desymmetrization of the [Zn(TPP)] domain. This most noticeably affects the orthoprotons $\left(\mathrm{H}^{\mathrm{D} 2}, \mathrm{H}^{\mathrm{E} 2}\right.$ and $\left.\mathrm{H}^{\mathrm{G} 2}\right)$ of the phenyl rings and the remaining protons in phenyl ring $\mathrm{D}$ (Fig. 1a). The shift to lower frequency of the signals for $\mathrm{H}^{\mathrm{D} 3}$ and $\mathrm{H}^{\mathrm{D} 4}$ compared to the metaand para-protons in rings $\mathrm{E}$ and $\mathrm{G}$ is attributed to the proximity of $\mathrm{H}^{\mathrm{D} 3}$ and $\mathrm{H}^{\mathrm{D} 4}$ to the arene ring $\mathrm{C}$. The ${ }^{13} \mathrm{C}$ NMR spectrum of 3 was assigned using HMQC and HMBC methods (Fig. S1 and $\mathrm{S} 2 \dagger)$.

Single crystals of $3 \cdot \mathrm{Me}_{2} \mathrm{CO}$ were grown by slow evaporation of solvent from an acetone solution of 3 . The acetone adduct of 3 (Fig. 2) crystallizes in the monoclinic space group $P 2_{1} / c$. The $\{\mathrm{Zn}(\mathrm{TPP})\}$ unit is structurally as expected with the atom $\mathrm{Zn} 1$ lying only $0.14 \AA$ out of the mean plane of the porphyrin $\mathrm{N}_{4}$-donor set; $\mathrm{Zn}-\mathrm{N}$ bond distances and $\mathrm{N}-\mathrm{Zn}-\mathrm{N}$ bond angles are given in the caption to Fig. 2 . The acetone molecule is axially coordinated and the $\mathrm{Zn}-\mathrm{O}$ bond distance of 2.345(4) $\AA$ is within the range of observed for axial ketones in porphyrinato zinc(II) complexes. ${ }^{34}$ The twist angles between the planes of the phenyl rings with C3, C14, C25 and C36 and the porphyrin core are in the range 59.8 and $67.4^{\circ}$; for the phenyl ring containing $\mathrm{C} 45$, the 


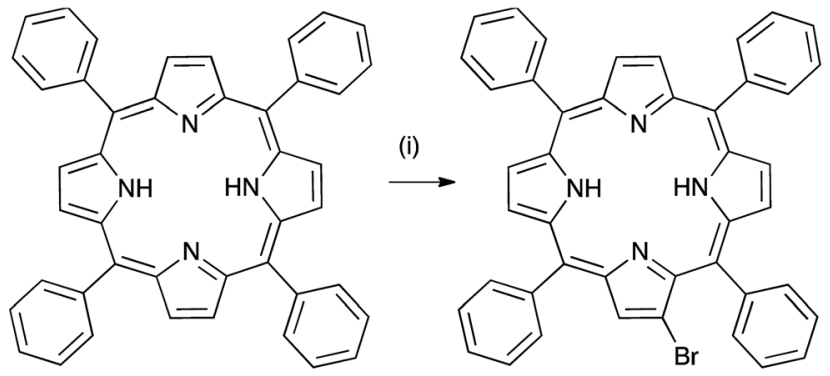

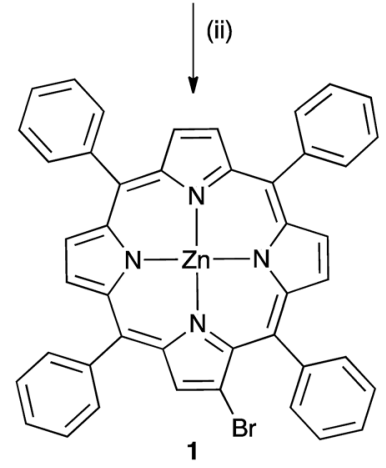

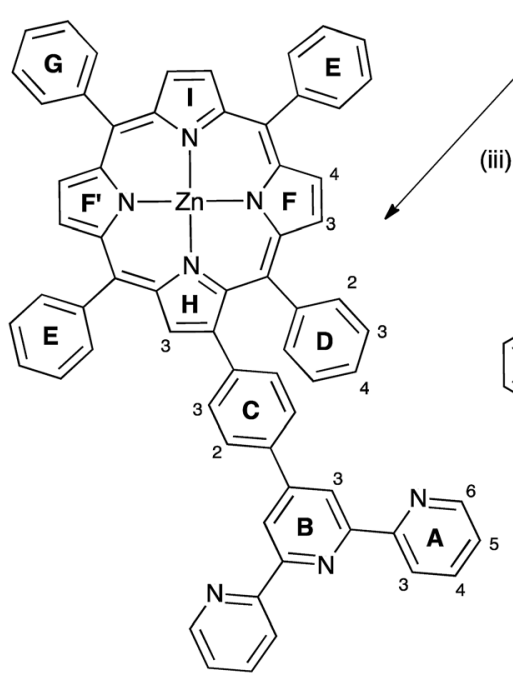<smiles>OB(O)c1ccc(-c2cc(-c3ccccn3)nc(-c3ccccn3)c2)cc1</smiles>
2

3

Scheme 1 Synthetic route to 3. Conditions: (i) $\mathrm{NBS}, \mathrm{CHCl}_{3}$ reflux, $4.5 \mathrm{~h}$; (ii) 2 equivalents $\mathrm{Zn}(\mathrm{OAc})_{2}$ in $\mathrm{MeOH}$; room temperature, $17 \mathrm{~h}$, $\mathrm{CHCl}_{3}$; (iii) $\mathrm{K}_{2} \mathrm{CO}_{3}, 2$ in toluene/ $\mathrm{H}_{2} \mathrm{O},\left[\mathrm{Pd}\left(\mathrm{PPh}_{3}\right)_{4}\right], 4 \mathrm{~h}, 120{ }^{\circ} \mathrm{C}$ under microwave conditions.

corresponding angle is $61.9^{\circ}$, and the pyridine ring with N6 is then twisted through $32.5^{\circ}$ with respect to the plane of the phenyl spacer. The similar twist angles for the arene rings containing C36 and C45 permit the rings to engage in a $\pi$-stacking interaction although the $16.2^{\circ}$ angle between their planes is not ideal; the centroid $\cdots$ centroid distance is $3.51 \AA$. The tpy unit is virtually planar (angles between planes of adjacent pyridine rings are 2.7 and $\left.6.2^{\circ}\right)$. The planarity is associated with a face-to-face $\pi$-interaction between centrosymmetric pairs of tpy units (Fig. 3a). The centrosymmetric pairing of the $\{\mathrm{Zn}(\mathrm{TPP})\}$ units (Fig. $3 \mathrm{~b}$ ) is typical and has been extensively discussed in the literature. ${ }^{35}$
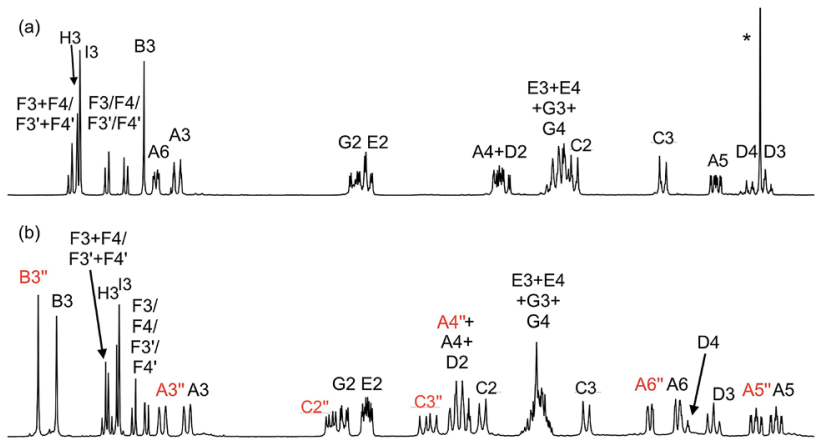

\begin{tabular}{llllllllllllllllllllll}
\hline 9.1 & 9.0 & 8.9 & 8.8 & 8.7 & 8.6 & 8.5 & 8.4 & 8.3 & 8.2 & 8.1 & 8.0 & 7.9 & 7.8 & 7.7 & 7.6 & 7.5 & 7.4 & 7.3 & 7.2
\end{tabular}

Fig. 1 Aromatic region of the $500 \mathrm{MHz}$ NMR spectra of (a) 3 (in $\mathrm{CDCl}_{3}$ ) and (b) $[\mathrm{Ru}(3)(4)]\left[\mathrm{PF}_{6}\right]_{2}$ (in $\mathrm{CD}_{3} \mathrm{CN}$ ). * = residual $\mathrm{CHCl}_{3}$. Chemical shifts in $\delta /$ ppm. See Schemes 1 and 2 for atom labels.

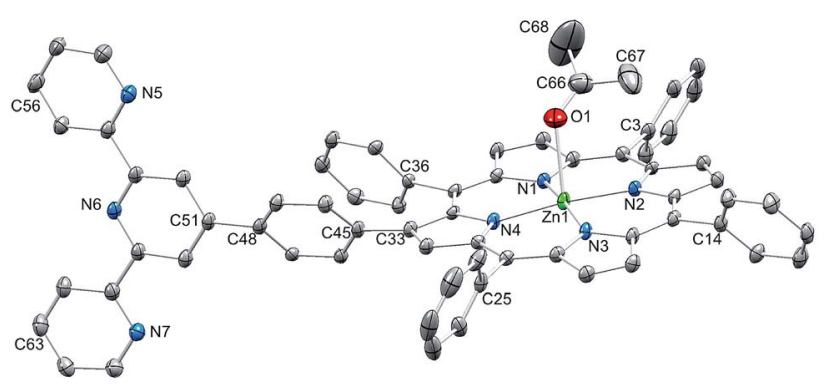

Fig. 2 Structure of $3 \cdot \mathrm{Me}_{2} \mathrm{CO}$ with $\mathrm{H}$ atoms omitted for clarity; thermal ellipsoids plotted at $30 \%$ probability level. Selected bond metrics: Zn1$\mathrm{N} 1=2.034(3), \mathrm{Zn} 1-\mathrm{N} 2=2.062(3), \mathrm{Zn} 1-\mathrm{N} 3=2.042(3), \mathrm{Zn} 1-\mathrm{N} 4=$ 2.062(3), $\mathrm{Zn} 1-\mathrm{O} 1=2.345(4), \mathrm{C} 66-\mathrm{O} 1=1.215(8) \AA ; \mathrm{N} 1-\mathrm{Zn} 1-\mathrm{N} 2=$ 89.69(14), N2-Zn1-N3 = 89.27(13), N1-Zn1-N4 = 89.52(13), N3$\mathrm{Zn} 1-\mathrm{N} 4=90.51(13), \mathrm{N} 1-\mathrm{Zn} 1-\mathrm{O} 1=82.10(16), \mathrm{N} 2-\mathrm{Zn} 1-\mathrm{O} 1=$ 88.43(16), N3-Zn1-O1 = 106.45(16), N4-Zn1-O1 = 98.11(16) .

\section{Synthesis and characterization of $\left.[\mathrm{Ru}(3)(4)] \mathrm{PF}_{6}\right]_{2}$}

Heteroleptic $\left[\mathrm{Ru}(\text { tpy-I)(tpy-II) }]^{2+}\right.$ complexes are most conveniently made by treating $\mathrm{RuCl}_{3} \cdot 3 \mathrm{H}_{2} \mathrm{O}$ sequentially with the two ligands, the second step in the presence of $N$-ethylmorpholine for the reduction of ruthenium(III) to ruthenium(II). In principle, two approaches could be used to prepare $[\mathrm{Ru}(3)(4)]\left[\mathrm{PF}_{6}\right]_{2}$ : (i) reaction of $\mathrm{RuCl}_{3} \cdot 3 \mathrm{H}_{2} \mathrm{O}$ with 3 , followed by treatment with 4 in the presence of $N$-ethylmorpholine, or (ii) reaction of $\mathrm{RuCl}_{3} \cdot 3 \mathrm{H}_{2} \mathrm{O}$ with $\mathbf{4}$, followed by treatment with 3 in the presence of $\mathrm{N}$-ethylmorpholine. Both methods were tried but the former resulted in cleavage of the porphyrin and tpy domains in 3. Thus, $[\mathrm{Ru}(3)(4)]\left[\mathrm{PF}_{6}\right]_{2}$ was prepared as shown in Scheme 2 by treatment of $\mathrm{RuCl}_{3} \cdot 3 \mathrm{H}_{2} \mathrm{O}$ with 4 to give the insoluble species $[\mathrm{Ru}(\mathbf{4})$ $\left.\mathrm{Cl}_{3}\right]$ which was further reacted with 3 in the presence of $N$-ethylmorpholine to give (after anion exchange and workup) $[\mathrm{Ru}(3)(4)]\left[\mathrm{PF}_{6}\right]_{2}$ as a purple powder in $26 \%$ yield.

The ESI mass spectrum of $[\mathrm{Ru}(3)(4)]\left[\mathrm{PF}_{6}\right]_{2}$ showed a peak envelope at $\mathrm{m} / \mathrm{z} 765.6$ with peaks at half-mass intervals consistent with assignment to $[\mathrm{Ru}(3)(4)]^{2+}$. In addition to signals for aromatic protons, the ${ }^{1} \mathrm{H}$ NMR spectrum of a $\mathrm{CD}_{3} \mathrm{CN}$ solution of $[\mathrm{Ru}(3)(4)]\left[\mathrm{PF}_{6}\right]_{2}$ exhibited multiplets at $\delta 4.14$ and $1.35 \mathrm{ppm}$, 


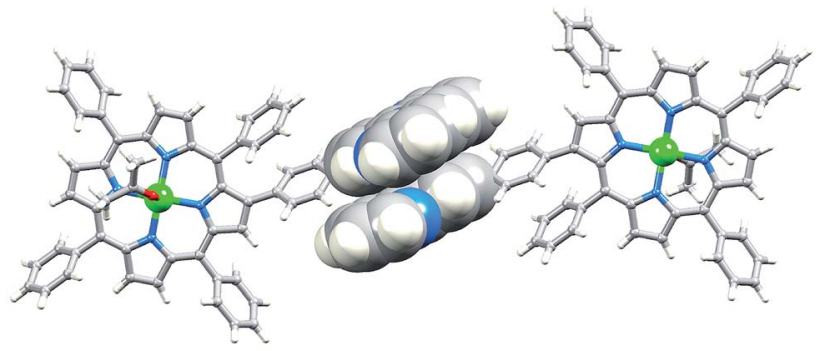

(a)

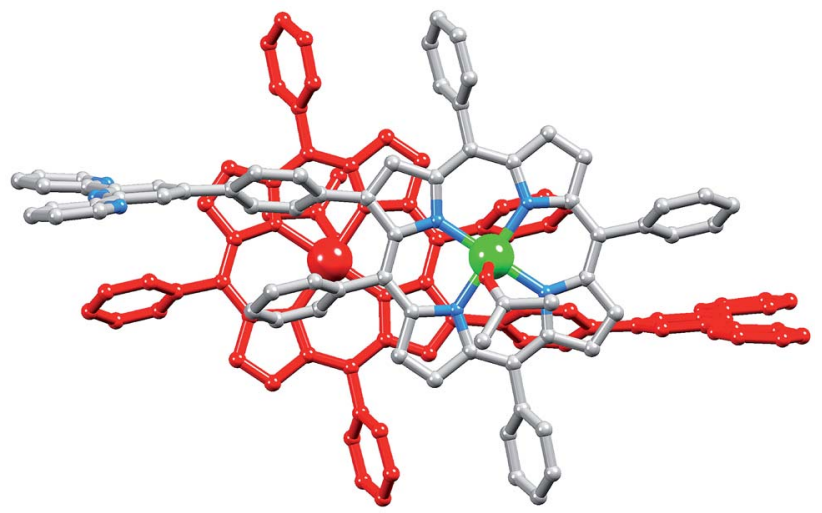

(b)

Fig. 3 (a) Stacking of centrosymmetric pairs of tpy domains in $3 \cdot \mathrm{Me}_{2} \mathrm{CO}$; separation of central pyridine rings $=3.30 \AA$ and centroid $\cdots$ centroid distance $=3.71 \AA$. (b) Stacking of centrosymmetric pairs of $\{Z \mathrm{n}(\mathrm{TPP})\}$ units; $\mathrm{Zn}(1) \cdots \mathrm{Zn}(1)^{i}=6.903(1) \AA$ (symmetry code $i=2-x, 1-$ $y, 2-z)$.

arising from the ethyl groups of the phosphonate ester group in ligand 4 . The relative integrals of these resonances compared to the aromatic region confirmed that no ester hydrolysis occurred during the complex formation; partial hydrolysis of $\mathrm{PO}(\mathrm{OEt})_{2^{-}}$ functionalized tpy ligands has been observed during the formation of some ruthenium(II) complexes. ${ }^{36-38}$ The aromatic region of the $[\mathrm{Ru}(3)(4)]\left[\mathrm{PF}_{6}\right]_{2}$ is shown in Fig. $1 \mathrm{~b}$ and its signature is consistent with the presence of two different tpy domains. COSY, NOESY, HMQC and HMBC methods were used to assign the signals in the ${ }^{1} \mathrm{H}$ and ${ }^{13} \mathrm{C}$ NMR spectra, although not all quaternary signals could be unambiguously ascribed (see Experimental section). A starting point for distinguishing between the two tpy ligands was assignment of the ipso-C atom of the arene ring attached to the phosphonate group; the resonance for $\mathrm{C}^{\mathrm{C} 4^{\prime \prime}}$ (Scheme 2) was a doublet $\left(J_{\mathrm{PC}}=189 \mathrm{~Hz}\right.$ ) at $\delta 131.8$ ppm. A comparison of Fig. 1a with Fig. 1b shows that formation of the $\left\{\mathrm{Ru}(\mathrm{tpy})_{2}\right\}^{2+}$ domain leads to the characteristic shift of the $\mathrm{H}^{\mathrm{A6}}$ signal to lower frequency $(\delta 8.76 \mathrm{ppm}$ in 3 to $\delta 7.47 \mathrm{ppm}$ in $\left.[\mathrm{Ru}(3)(4)]\left[\mathrm{PF}_{6}\right]_{2}\right)$; the signal for $\mathrm{H}^{\mathrm{A} 6^{\prime \prime}}(\delta 7.53 \mathrm{ppm})$ appears close to that for $\mathrm{H}^{\mathrm{A} 6}$, consistent with these protons lying over the ring current of the adjacent tpy ligand in the octahedral $\left\{\mathrm{Ru}(\mathrm{tpy})_{2}\right\}^{2+}$ unit.

\section{Cyclic voltammetry}

The redox behaviour of $[\mathrm{Zn}(\mathrm{TPP})]$ has previously been described, ${ }^{39}$ and the potentials for the reversible one-electron<smiles>CCOP(=O)(OCC)c1ccc(-c2cc(-c3ccccn3)nc(-c3ccccn3)c2)cc1</smiles><smiles></smiles>

(ii), (iii)

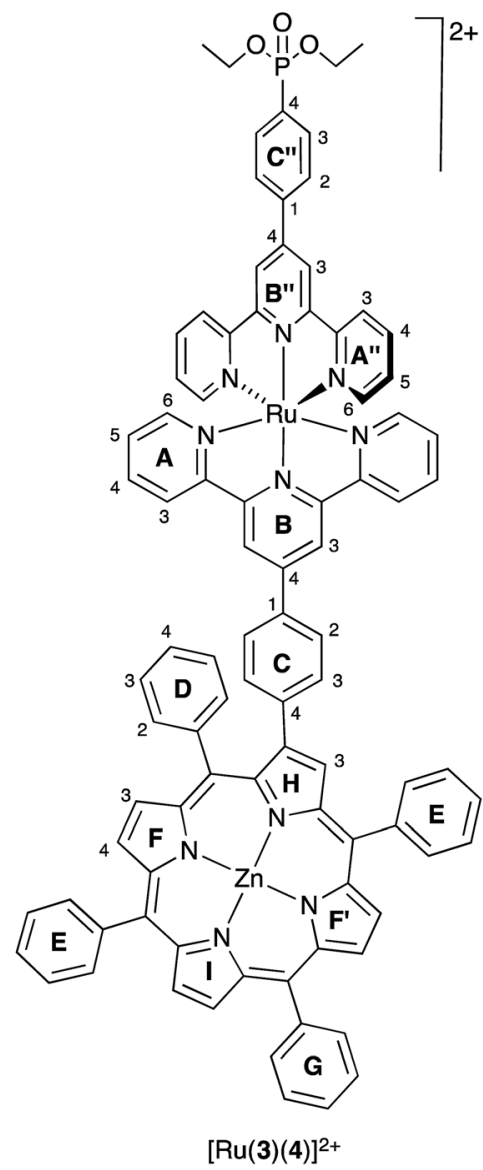

Scheme 2 Synthesis of $[\mathrm{Ru}(3)(4)]^{2+}$, isolated as the $\left[\mathrm{PF}_{6}\right]^{-}$salt. Conditions: $\mathrm{RuCl}_{3} \cdot 3 \mathrm{H}_{2} \mathrm{O}$, EtOH, reflux, $4.5 \mathrm{~h}$; (ii) 2, EtOH, N-ethylmorpholine, $140{ }^{\circ} \mathrm{C}, 20$ min under microwave conditions; (iii) $\mathrm{NH}_{4} \mathrm{PF}_{6}$. Atom labels for NMR spectra of $[\mathrm{Ru}(3)(4)]\left[\mathrm{PF}_{6}\right]_{2}$ are shown.

reduction and oxidation processes provide reference data for the interpretation of the electrochemical behaviour of the new conjugate species. Data are summarized in Table 1 along with the electrochemical band-gaps, $\Delta E_{1 / 2}$. The electrochemistry of 3 and $[\mathrm{Ru}(3)(4)]\left[\mathrm{PF}_{6}\right]_{2}$ was studied using cyclic voltammetry. Like [Zn(TPP)], compound 3 exhibits two oxidative processes (Table 1 and Fig. 4a), reversible and reproducible over three scans, which 
Table 1 Redox potentials for 3 in $\mathrm{CH}_{2} \mathrm{Cl}_{2}$ and $[\mathrm{Ru}(3)(4)]\left[\mathrm{PF}_{6}\right]_{2}$ in $\mathrm{MeCN}$ solution compared to [ $\mathrm{Zn}(\mathrm{TPP})]$ in $\mathrm{CH}_{2} \mathrm{Cl}_{2}$ measured using cyclic voltammetry. Potentials are referenced to $\mathrm{Fc} / \mathrm{FC}^{+}$with $0.1 \mathrm{M}\left[{ }^{n} \mathrm{Bu}_{4}\right]\left[\mathrm{PF}_{6}\right]$ as supporting electrolyte and a scan rate of $0.1 \mathrm{~V} \mathrm{~s}^{-1}$ (ir = irreversible, $\mathrm{qr}=$ quasi-reversible) $^{a}$

\begin{tabular}{lllll}
\hline Compound & $E_{1 / 2}^{\mathrm{ox}} / \mathrm{V}$ & $E_{1 / 2}^{\mathrm{red}} / \mathrm{V}$ & $\Delta E_{1 / 2} / \mathrm{V}^{b}$ & Reference \\
\hline$[\mathrm{Zn}(\mathrm{TPP})]$ & $+0.42(82)$ & $-1.79(79)$ & 2.21 & 39 \\
3 & $+0.71(81)$ & & & \\
& $+0.34(57)$ & $-1.76^{\mathrm{ir}}$ & 2.10 & This work \\
& $+0.66(84)$ & $-1.97^{\mathrm{ir}}$ & & \\
& & $-2.09^{\mathrm{ir}}$ & & This work \\
& & $-2.27^{\mathrm{ir}}$ & & \\
{$[\mathrm{Ru}(3)(4)]\left[\mathrm{PF}_{6}\right]_{2}$} & $+0.39(56)$ & $-1.56^{\mathrm{ir}}$ & 1.95 & \\
& $+0.67(56)$ & $-1.87^{\mathrm{ir}}$ & & \\
& $+0.88(65)$ & $-2.21^{\mathrm{ir}}$ & & \\
${ }^{a}$ Values in parenthesis $=E_{\mathrm{pc}}-E_{\mathrm{pa}}$ in $\mathrm{mV} .{ }^{b} \Delta E_{1 / 2}=E_{1 / 2}^{\mathrm{ox}}-E_{1 / 2}^{\text {red }}$
\end{tabular}

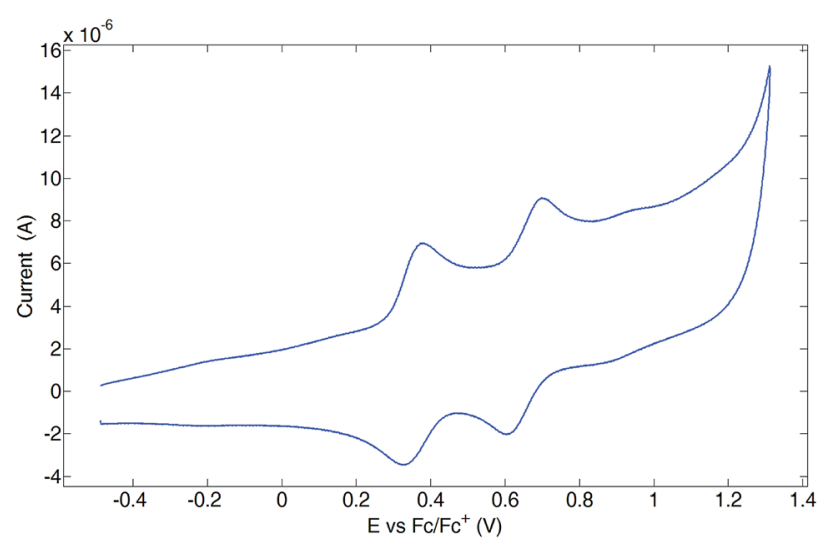

(a)

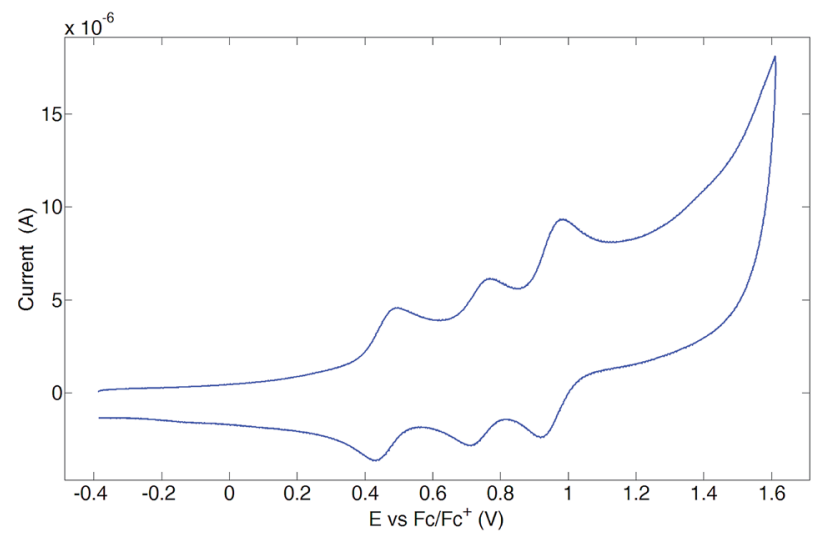

(b)

Fig. 4 Oxidative processes in the cyclic voltammograms of (a) 3 and (b) $[\mathrm{Ru}(3)(4)]\left[\mathrm{PF}_{6}\right]_{2}$. For conditions, see Table 1.

are assigned to $[\mathrm{Zn}(\mathrm{TPP})] /[\mathrm{Zn}(\mathrm{TPP})]^{+}$and $[\mathrm{Zn}(\mathrm{TPP})]^{+} /[\mathrm{Zn}(\mathrm{TPP})]^{2+}$ couples. Reduction processes were poorly defined in the $\mathrm{CV}$ (Fig. S3†) but could be distinguished using differential pulse voltammetry; $E_{1 / 2}^{\text {red }}$ values are given in Table 1 . By comparison with data for $[\mathrm{Zn}(\mathrm{TPP})]$, the first reduction at $-1.76 \mathrm{~V}$ is presumably centred on the $\{\mathrm{Zn}(\mathrm{TPP})\}$ domain in $\mathbf{3}$ and the processes at more negative potential are phenyltpy-centred. On going to $[\mathrm{Ru}(3)(4)]\left[\mathrm{PF}_{6}\right]_{2}$, the potential of the $[\mathrm{Zn}(\mathrm{TPP})]$-centred oxidative couples are little affected (Table 1). An additional oxidation process at $+0.88 \mathrm{~V}$ (Table 1 and Fig. $4 \mathrm{~b}$ ) is assigned to the $\mathrm{Ru}^{2+} / \mathrm{Ru}^{3+}$ couple, and compares well with $+0.895 \mathrm{~V}$ reported for $\left[\mathrm{Ru}(\mathrm{Phtpy})_{2}\right]\left[\mathrm{PF}_{6}\right]_{2}{ }^{40}[\mathrm{Ru}(3)(4)]\left[\mathrm{PF}_{6}\right]_{2}$ undergoes three irreversible reduction processes.

\section{Absorption spectra and spectroelectrochemistry}

Fig. 5 compares the solution absorption spectra of 1, 3 and $[\mathrm{Ru}(3)(4)]\left[\mathrm{PF}_{6}\right]_{2}$. The spectrum of compound 1 shows the typical features of a metallated porphyrin, ${ }^{39,41}$ the intense Soret band at $425 \mathrm{~nm}\left(\varepsilon=660000 \mathrm{dm}^{3} \mathrm{~mol}^{-1} \mathrm{~cm}^{-1}\right)$ arising from the $\mathrm{S}_{2} \leftarrow \mathrm{S}_{0}$ transition, and weaker $\mathrm{Q}$ bands resulting from the vibrational structure $((0,0)$ and $(0,1))$ from the $S_{1} \leftarrow S_{0}$ transition (558 and $597 \mathrm{~nm}, \varepsilon=22000$ and $7600 \mathrm{dm}^{3} \mathrm{~mol}^{-1} \mathrm{~cm}^{-1}$, respectively). On going to compound 3 , an additional $\pi$-conjugated system in the $\beta$-pyrrolyl position is introduced. The Soret band moves slightly and decreases in intensity $\left(427 \mathrm{~nm}, \varepsilon=520000 \mathrm{dm}^{3} \mathrm{~mol}^{-1}\right.$ $\mathrm{cm}^{-1}$ ), while the Q bands change little (Fig. 5, 560 and $599 \mathrm{~nm}$, $\varepsilon=26000,9500 \mathrm{dm}^{3} \mathrm{~mol}^{-1} \mathrm{~cm}^{-1}$, respectively). The highenergy bands (around $285 \mathrm{~nm}$, green trace in Fig. 4) are attributed to $\pi^{*} \leftarrow \pi$ transitions localized on the phenyltpy domain.

Upon formation of the ruthenium(II) complex $[\mathrm{Ru}(3)(4)]$ $\left[\mathrm{PF}_{6}\right]_{2}$, the high-energy bands (below $350 \mathrm{~nm}$ ) approximately doubled in intensity with respect to the absorptions in $\mathbf{3}$ (blue trace in Fig. 5), consistent with the presence of two tpy domains. The Soret band again decreases in intensity $\left(\varepsilon=370000 \mathrm{dm}^{3}\right.$ $\mathrm{mol}^{-1} \mathrm{~cm}^{-1}$ ) but is little shifted from the free ligand 3 (425 versus $427 \mathrm{~nm}$ ), providing evidence for electronic communication between the porphyrin and tpy domains. Fig. 5 shows that there is also little difference in the $\mathrm{Q}$ bands comparing 3 with $[\mathrm{Ru}(3)(4)]\left[\mathrm{PF}_{6}\right]_{2}$, (in the complex, 599 and $559 \mathrm{~nm}, \varepsilon=28000,10000 \mathrm{dm}^{3} \mathrm{~mol}^{-1} \mathrm{~cm}^{-1}$, respectively). Confirmation of the presence of the $\left\{\mathrm{Ru}(\mathrm{tpy})_{2}\right\}^{2+}$ chromophore comes from the appearance of the broad band at $492 \mathrm{~nm}$ arising from the ${ }^{1}$ MLCT absorption of this chromophore. ${ }^{42}$

We commence the spectroelectrochemical discussion by presenting the results obtained from a study of a $\mathrm{CH}_{2} \mathrm{Cl}_{2}$ solution of compound 3. Fig. 6a shows a superimposition of the

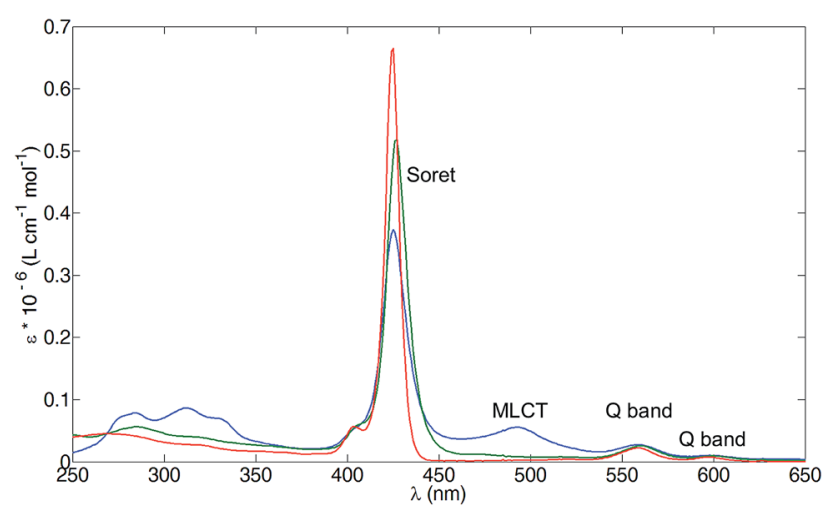

Fig. 5 Absorption spectra of 1 (red line, EtOH, $\lambda_{\max }=425 \mathrm{~nm}$ ), 3 (green line, $\mathrm{EtOH}, \lambda_{\max }=427 \mathrm{~nm}$ ) and $[\mathrm{Ru}(3)(4)]\left[\mathrm{PF}_{6}\right]_{2}$ (blue line, $\mathrm{MeCN}$, $\lambda_{\max }=425 \mathrm{~nm}$ ). Concentration $=1 \times 10^{-6} \mathrm{~mol} \mathrm{dm}^{-3}$. 
absorption spectra of 3 recorded before and after an oxidative cycle. The complete set of scans for the oxidative cycle are shown in Fig. 6b. The irreversible changes are consistent with the literature data for $[\mathrm{Zn}(\mathrm{TPP})] \cdot{ }^{43}$ Initial oxidation leads to a $\pi$-radical cation, the Soret band of which is about half as intense as the original band, and the $\mathrm{Q}$ bands are replaced with an absorption with $\lambda_{\max } \approx 650 \mathrm{~nm}$. The second oxidation leads to a dication which is unstable on the experimental timescale. The results of the spectroelectrochemical reductive cycle for 3 are depicted in Fig. $\mathrm{S} 4 \dagger$ and are again consistent with the literature data for [ $\mathrm{Zn}(\mathrm{TPP})]$.

The oxidative and reductive cycles of the spectroelectrochemical measurements carried out on an MeCN solution of $[\mathrm{Ru}(3)(4)]\left[\mathrm{PF}_{6}\right]_{2}$ are shown in Fig. 7 and 8. At the end of the oxidative cycle, the regeneration of the absorptions associated with the $\left\{\mathrm{Ru}(\mathrm{tpy})_{2}\right\}^{2+}$ domain (the MLCT band at $492 \mathrm{~nm}$, and the bands at 284 and 310 arising from the phenyltpy $\pi^{*} \leftarrow \pi$ transitions) confirms the reversibility of these processes. In contrast, the oxidation of the $[\mathrm{Zn}(\mathrm{TPP})]$ moiety within the complex is irreversible, the processes mimicking those of compound 3 with the exception that the band at $650 \mathrm{~nm}$ is now transient. This may be due to over-oxidation of the porphyrin core. During the reductive cycle (Fig. 8), the absorptions arising

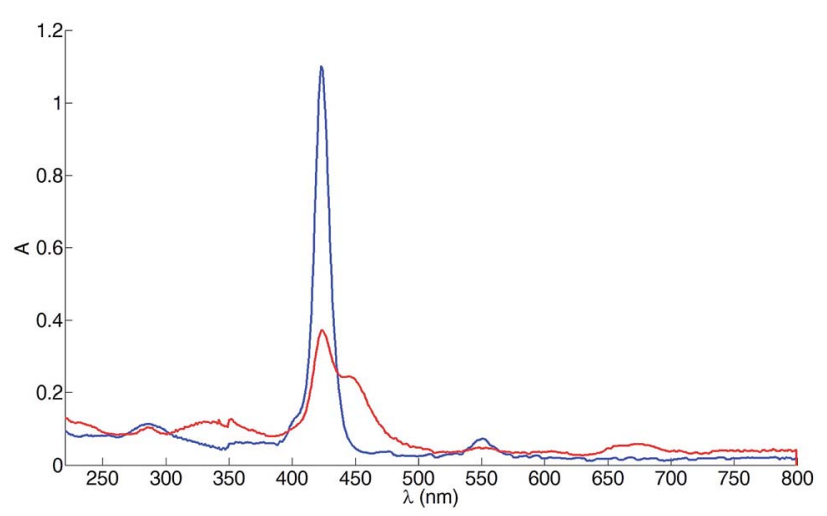

(a)

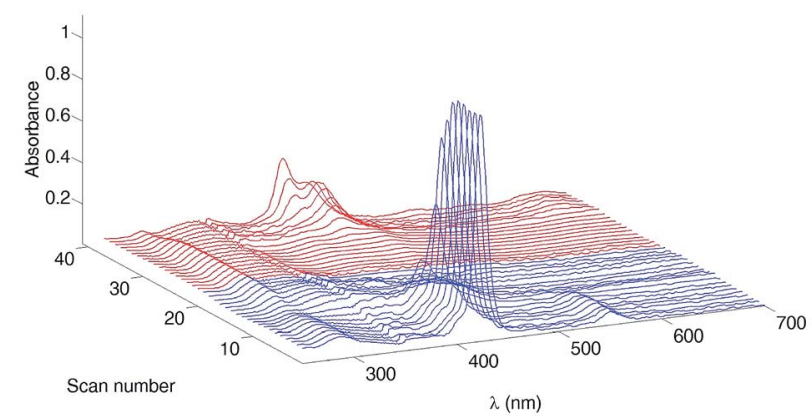

(b)

Fig. 6 Spectroelectrochemical data for the oxidative cycle of 3 ( $\approx 1 \mathrm{mM}$ in $\mathrm{CH}_{2} \mathrm{Cl}_{2}$, [ $\left.{ }^{n} \mathrm{Bu}_{4} \mathrm{~N}\right]\left[\mathrm{PF}_{6}\right]$ supporting electrolyte). (a) Absorption spectra before (blue line) and after (red line) the oxidative cycle. (b) A spectrum was recorded every $0.1 \mathrm{~V}$, starting from $0 \mathrm{~V}$ (first blue line at the front) to $+1.8 \mathrm{~V}$ (last blue line) and back from $+1.8 \mathrm{~V}$ (first red line) to $0 \mathrm{~V}$ (last red line). The potential is referenced with respect to the $\mathrm{Fc} / \mathrm{Fc}^{+}$ redox couple with the same cell under the same experimental conditions.

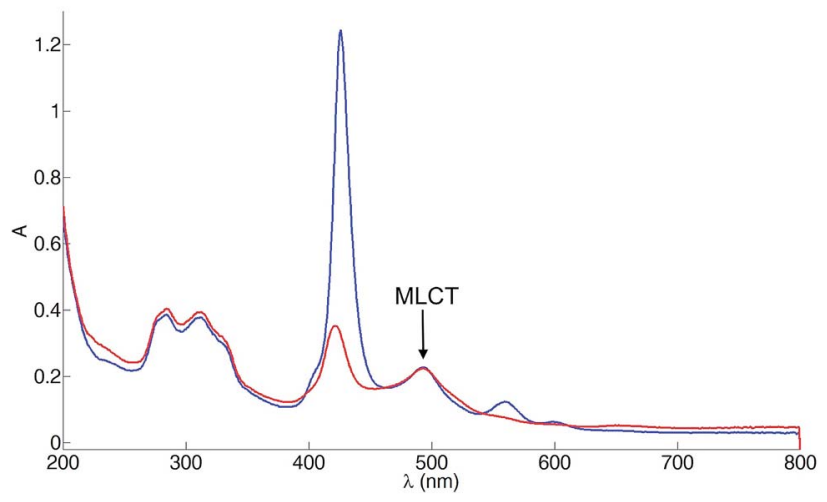

(a)

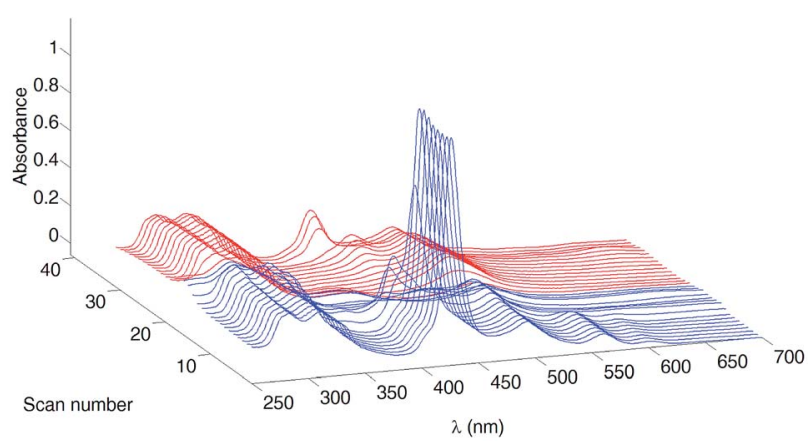

(b)

Fig. 7 Spectroelectrochemical data for the oxidative cycle of $[\mathrm{Ru}(3)(4)]$ $\left[\mathrm{PF}_{6}\right]_{2}\left(\approx 1 \mathrm{mM}\right.$ in $\mathrm{MeCN},\left[{ }^{n} \mathrm{Bu}_{4} \mathrm{~N}\right]\left[\mathrm{PF}_{6}\right]$ supporting electrolyte). (a) Absorption spectra before (blue line) and after (red line) the oxidative cycle. (b) A spectrum was recorded every $0.1 \mathrm{~V}$, starting from $0 \mathrm{~V}$ (first blue line at the front) to $+1.5 \mathrm{~V}$ (last blue line) and back from $+1.5 \mathrm{~V}$ (first red line) to $0 \mathrm{~V}$ (last red line). See caption to Fig. 6 for referencing to $\mathrm{Fc} / \mathrm{Fc}^{+}$.

from both the porphyrin and $\left\{\mathrm{Ru}(\mathrm{tpy})_{2}\right\}^{2+}$ domains are irreversibly transformed. The irreversible changes to the Soret and $\mathrm{Q}$ bands are consistent with those observed for $\mathbf{3}$ and $[\mathrm{Zn}(\mathrm{TPP})]^{\mathbf{4 3}}$ while irreversible reduction processes centred on the phenyltpy units are responsible for the loss of the bands associated with the $\pi^{*} \leftarrow \pi$ and MLCT transitions. Fig. $9 \mathrm{~b}$ provides evidence for a transient band between 800 and $900 \mathrm{~nm}$, which can be assigned to the $[3]^{\cdot-}$ radical anion. ${ }^{44}$

\section{$[\mathrm{Ru}(3)(4)]\left[\mathrm{PF}_{6}\right]_{2}$ as a dye in DSCs}

Although phosphonic acid anchors ${ }^{45}$ bind more strongly than phosphonate esters, ${ }^{46}$ it is has been demonstrated that $\mathrm{TiO}_{2}$ surfaces can be functionalized using phosphonate esters ${ }^{47,48}$ with immobilization of the anchor taking place by hydrolysis of POR groups by surface-OH groups. ${ }^{49}$ We therefore investigated the use of $[\mathrm{Ru}(3)(4)]^{2+}$ as a dye in DSCs. First, we confirmed that the dye bound to a $\mathrm{TiO}_{2}$ surface. $\mathrm{TiO}_{2}$ electrodes (without a scattering layer) were soaked in an MeCN solution of $[\mathrm{Ru}(3)(4)]$ $\left[\mathrm{PF}_{6}\right]_{2}$ for 3 days, and were then washed and dried. The electrode retained a red colour similar to that of reference electrodes with adsorbed N719. Compared to N719, the additional spectral response that the Soret band imparts to $[\mathrm{Ru}(3)(4)]^{2+}$ is clear from the solid-state absorption spectra Fig. 9. Adsorbed 


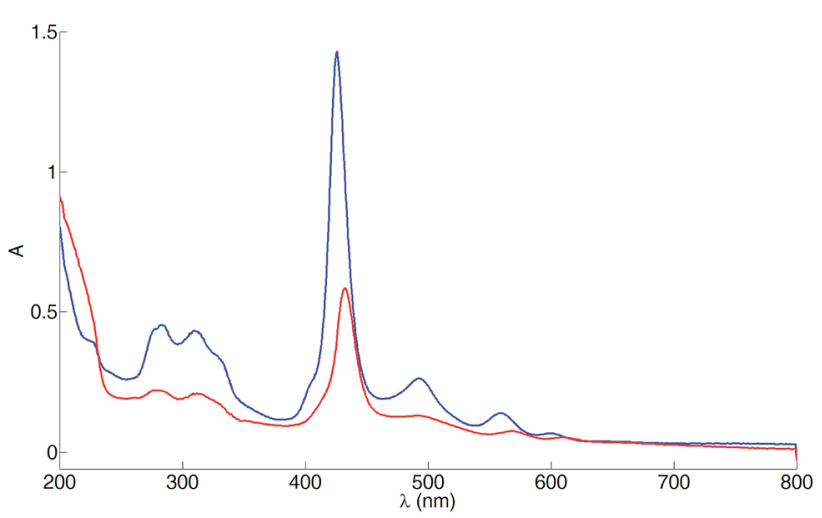

(a)

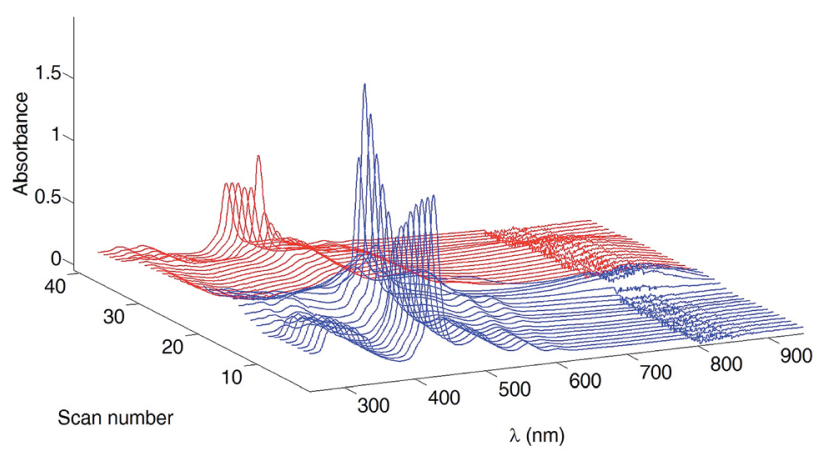

(b)

Fig. 8 Spectroelectrochemical data for the reductive cycle of $[\mathrm{Ru}(3)(4)]\left[\mathrm{PF}_{6}\right]_{2}$ ( $\approx 1 \mathrm{mM}$ in $\mathrm{MeCN},\left[{ }^{n} \mathrm{Bu}_{4} \mathrm{~N}\right]\left[\mathrm{PF}_{6}\right]$ supporting electrolyte). (a) Absorption spectra before (blue line) and after (red line) the reductive cycle. (b) A spectrum was recorded every $0.1 \mathrm{~V}$, starting from $0 \mathrm{~V}$ (first blue line at the front) to $-1.8 \mathrm{~V}$ (last blue line) and back from $-1.8 \vee$ (first red line) to $0 \vee$ (last red line). See caption to Fig. 6 for referencing to $\mathrm{Fc} / \mathrm{Fc}^{+}$.

$[\mathrm{Ru}(3)(4)]^{2+}$ exhibits $\lambda_{\max }$ at 432, 500, 564 and $641 \mathrm{~nm}$. The Soret band at $432 \mathrm{~nm}$ is red-shifted with respect to solution (425 nm) and absorptions at 500, 564 and $641 \mathrm{~nm}$ compare with bands in the solution spectrum (Fig. 5) at $492 \mathrm{~nm}$ (MLCT) and 560 and $600 \mathrm{~nm}$ (Q bands).

Photoanodes for n-type DSCs were made by immersion of FTO/TiO ${ }_{2}$ electrodes in an MeCN solution of $[\mathrm{Ru}(3)(4)]\left[\mathrm{PF}_{6}\right]_{2}$ for

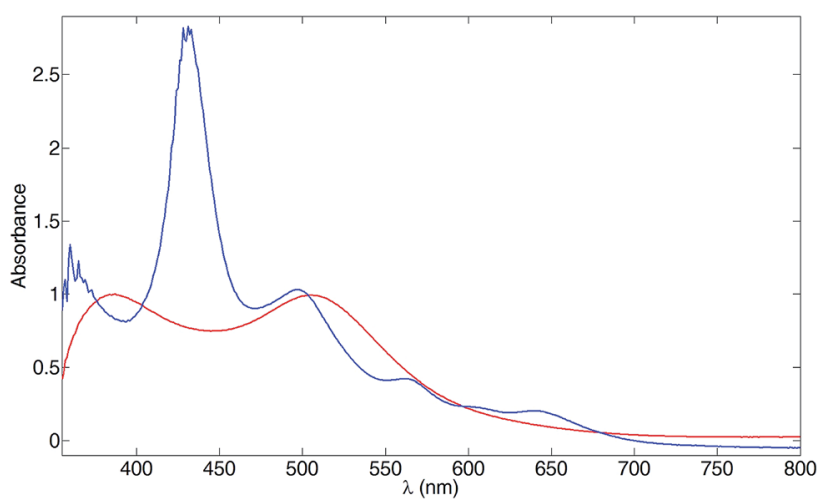

Fig. 9 Solid-state absorption spectra of transparent $\mathrm{TiO}_{2}$ electrodes with dyes $N 719$ (red) and $[R u(3)(4)]\left[P_{6}\right]_{2}$ (blue).
Table 2 Performance parameters of duplicate DSCs with $[R u(3)(4)]^{2+}$ and N719. Measurements were made on the day of DSC fabrication

\begin{tabular}{lclll}
\hline Dye & $J_{\mathrm{SC}} / \mathrm{mA} \mathrm{cm}^{-2}$ & $V_{\mathrm{OC}} / \mathrm{mV}$ & $\mathrm{ff} / \%$ & $\eta / \%$ \\
\hline N719 (cell 1) & 12.29 & 657 & 67 & 5.37 \\
N719 (cell 2) & 11.21 & 655 & 65 & 4.74 \\
{$[\mathrm{Ru}(3)(4)]^{2+}$ (cell 1) } & 0.10 & 333 & 52 & 0.02 \\
{$[\mathrm{Ru}(3)(4)]^{2+}$ (cell 2) } & 0.11 & 334 & 53 & 0.02
\end{tabular}

3 days, and reference electrodes were made similarly using an EtOH solution of N719. DSCs were fabricated using an $\mathrm{I}^{-} / \mathrm{I}_{3}{ }^{-}$ electrolyte (see Experimental section) and were fully masked. ${ }^{32,33}$ The reproducibility of performance parameters (Table 2) was confirmed using duplicate DSCs for each dye. Despite the enhanced light absorption of $[\mathrm{Ru}(3)(4)]^{2+}$ with respect to N719, the conversion efficiency $(\eta)$ is poor; the main contributing factor is the extremely low short-circuit current density $\left(J_{\mathrm{SC}}\right)$ electron injection. The open-circuit voltage $\left(V_{\mathrm{OC}}\right)$ is about half that of N719. In order to understand the poor performance of $[\mathrm{Ru}(3)(4)]^{2+}$ in DSCs, we have carried out a detailed investigation of the energy-transfer processes that follow excitation.

\section{Emission properties}

The solution emission behaviour of 3 and $[\mathrm{Ru}(3)(4)]\left[\mathrm{PF}_{6}\right]_{2}$ were investigated and compared to those of 1 . As discussed earlier, in the absorption spectrum of the latter, bands arising from $\mathrm{S}_{2} \leftarrow$ $S_{0}$ and $S_{1} \leftarrow S_{0}$ transitions are observed. Normally, for an organic molecule, population of the $S_{2}$ excited state is followed by fast internal conversion to $\mathrm{S}_{1},{ }^{50}$ and the emission spectrum can be related to the radiative decay of the lowest excited state of same multiplicity. [Zn(TPP)] is emissive from both the $S_{2}$ and $S_{1}$ states, although the fluorescence originating from the $S_{2}$ state has a much lower quantum yield and only a picosecond lifetime. ${ }^{51}$ Excitation of 1 at $400 \mathrm{~nm}$ (into the Soret shoulder) results in the emission spectrum shown in Fig. 10 with fluorescence from both the $S_{2}(431$ and $453 \mathrm{~nm})$ and $S_{1}(607$ and $659 \mathrm{~nm}$ ) excited states. The assignments were confirmed from the excitation spectra. Note that $\lambda_{\max }$ of the Soret band $(425 \mathrm{~nm})$ is too

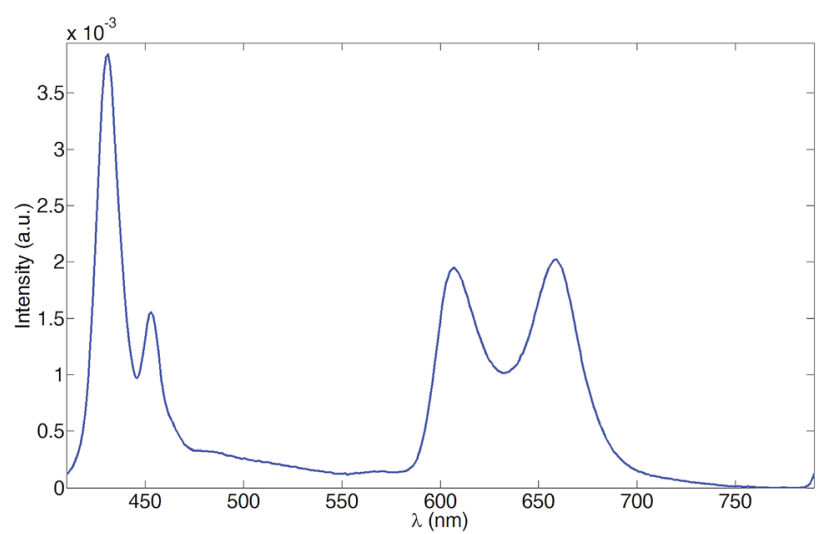

Fig. 10 Solution emission spectrum of $1\left(\mathrm{EtOH}, 1 \times 10^{-6} \mathrm{M}\right.$, room temperature). $\lambda_{\text {exc }}=400 \mathrm{~nm}$. 


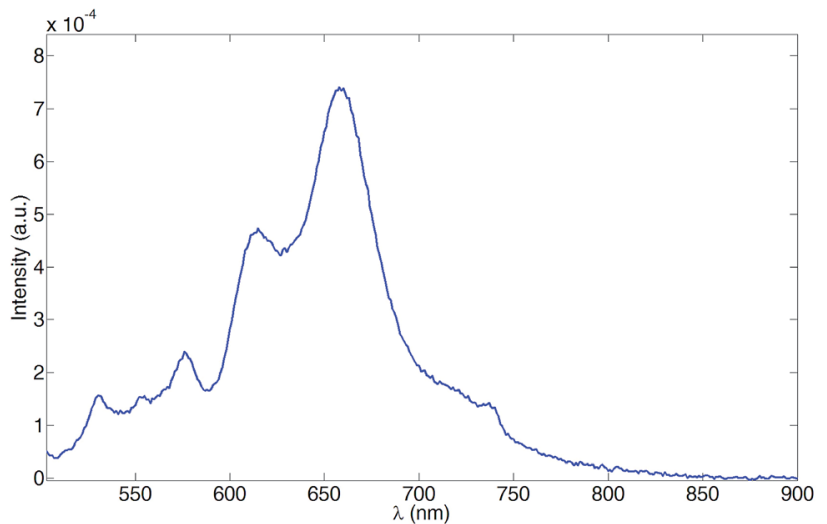

Fig. 11 Solution emission spectrum of $[\mathrm{Ru}(3)(4)]\left[\mathrm{PF}_{6}\right]_{2}(\mathrm{MeCN}, 1 \times$ $10^{-6} \mathrm{M}$, room temperature). $\lambda_{\text {exc }}=492 \mathrm{~nm}$.

close to the $\lambda_{\mathrm{em}}^{\max }$ of 431 and $453 \mathrm{~nm}$ from the $\mathrm{S}_{2}$ fluorescence to observe these emissions using $\lambda_{\text {exc }}=425 \mathrm{~nm}$. Excitation into the $\mathrm{Q}$ bands of 1 leads to the $\mathrm{S}_{1}$ emissions at 607 and $659 \mathrm{~nm}$.

The emission spectrum of compound 3 does not display an $\mathrm{S}_{2}$ fluorescence. Excitation into either the Soret or $\mathrm{Q}$ bands leads to emission at 613 and $660 \mathrm{~nm}$. Interestingly it is possible to detect porphyrin fluorescence even upon exciting into the tpy bands $\left(\lambda_{\text {exc }}=285\right.$ and $320 \mathrm{~nm}$ ). Since the tpy absorption is well separated from the porphyrin absorption bands, this is a clear indication of intramolecular energy transfer. The energetics of the system are favourable for an energy transfer from the $\left(\pi-\pi^{*}\right)$ tpy excited states (upper lying levels) to the $\mathrm{S}_{2}$ state (lower level), followed by internal conversion to $\mathrm{S}_{1}$ and radiative decay.

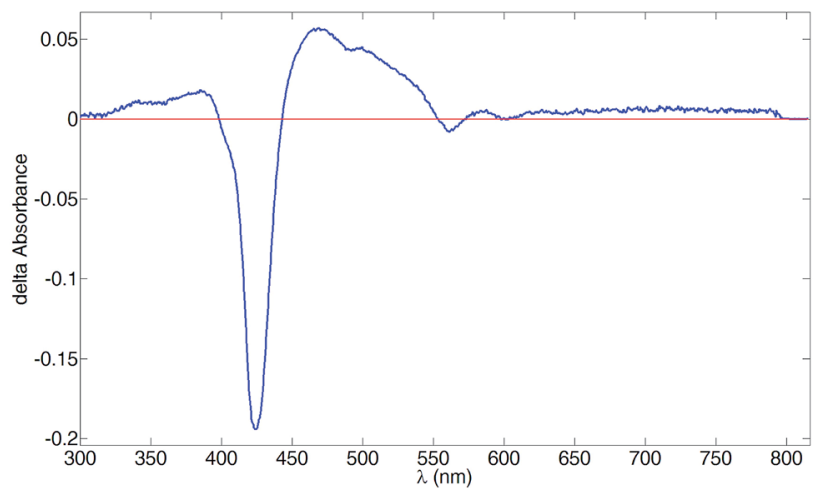

(a)

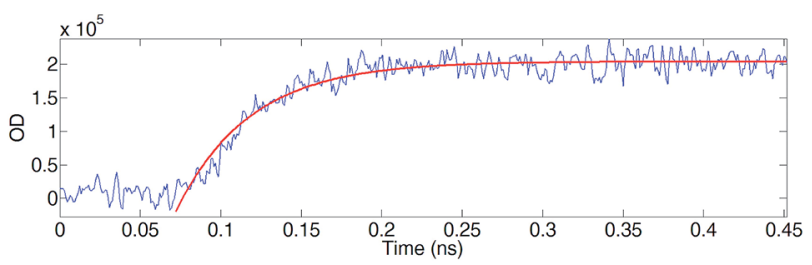

(b)

Fig. 12 (a) Transient absorption spectrum of $[\mathrm{Ru}(3)(4)]\left[\mathrm{PF}_{6}\right]_{2}(\mathrm{MeCN}$, $\approx 2 \times 10^{-6} \mathrm{M}$, room temperature). $\lambda_{\mathrm{exc}}=532 \mathrm{~nm}$. Acquisition time $200 \mathrm{~ns}, 5$ acquisitions without time delay. (b) Temporal evolution of the optical density between 440 and $463 \mathrm{~nm}$ after excitation at $532 \mathrm{~nm}$ with laser pulses of 30 ps duration.

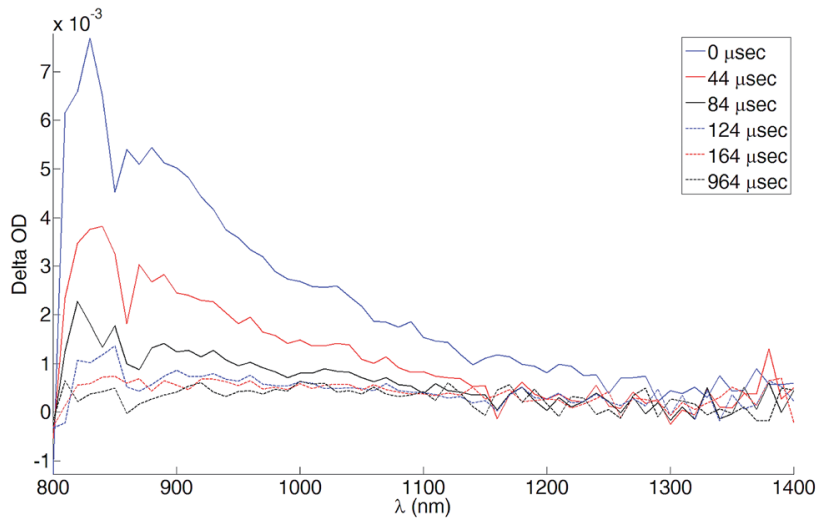

Fig. $13 \mathrm{NIR}$ transient absorption spectra of $[\mathrm{Ru}(3)(4)]\left[\mathrm{PF}_{6}\right]_{2}(\mathrm{MeCN}$, $\approx 2 \times 10^{-6} \mathrm{M}$, room temperature). $\lambda_{\text {exc }}=532 \mathrm{~nm}$. The spectra were reconstructed from decay curves recorded every $10 \mathrm{~nm}$.

Excitation spectra monitored at 560 and $600 \mathrm{~nm}$ confirm the presence of a broad peak centred at $285 \mathrm{~nm}$, in agreement with the involvement of a tpy absorption in the population of the $S_{1}$ state. The ruthenium(II) complex $[\mathrm{Ru}(3)(4)]\left[\mathrm{PF}_{6}\right]_{2}$ exhibits an emission behaviour similar to that of 3. Excitation into the tpy absorption bands $\left(\lambda_{\text {exc }}=284\right.$ and $\left.310 \mathrm{~nm}\right)$ results in porphyrin fluorescence $\left(\lambda_{\mathrm{em}}^{\mathrm{max}}=613\right.$ and $\left.661 \mathrm{~nm}\right)$. Moreover Fig. 11 shows that if the excitation is in the MLCT band $\left(\lambda_{\text {exc }}=492 \mathrm{~nm}\right)$, emission is again observed from the $S_{1}$ state of the porphyrin. It was not possible to detect $S_{2}$ fluorescence by exciting into the shoulder of the Soret band.

\section{Transient absorption spectra of $[\mathrm{Ru}(3)(4)]\left[\mathrm{PF}_{6}\right]_{2}$}

In order to further probe the emission behaviour of $[\mathrm{Ru}(3)(4)]\left[\mathrm{PF}_{6}\right]_{2}$, the transient absorption spectrum of the

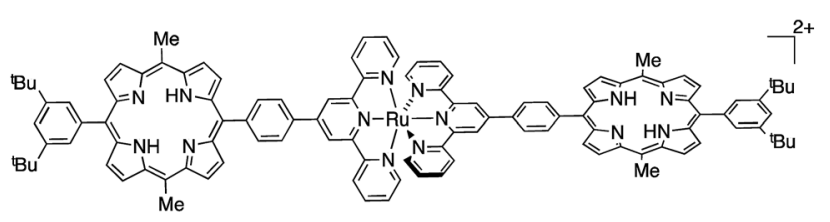

(a)

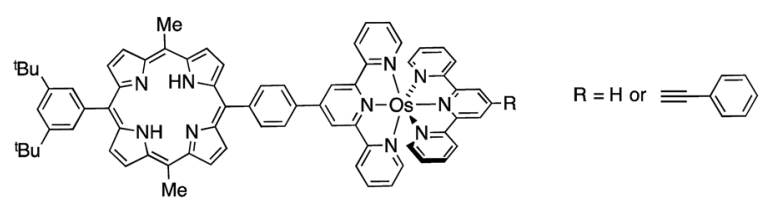

(b)

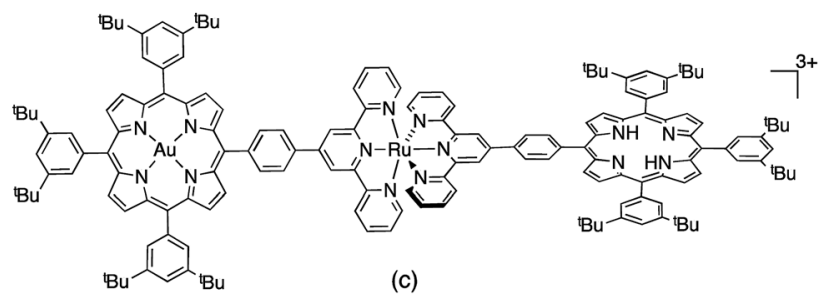

Scheme 3 Triads and dyads related to $[\mathrm{Ru}(3)(4)]\left[\mathrm{PF}_{6}\right]_{2}$ and reported by (a) and (b) Benniston et al., ${ }^{55,57}$ and (c) Flamigni et al. ${ }^{60}$ 
tpy $3.55 \mathrm{eV}$

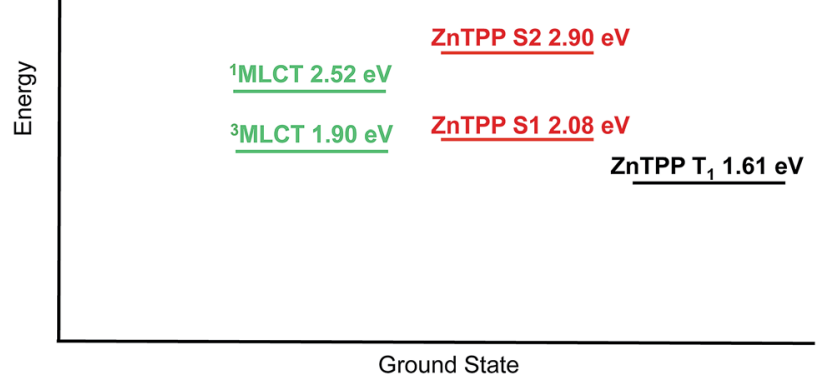

Fig. 14 Energetic level diagram for $[\mathrm{Ru}(3)(4)]^{2+}$.

complex was recorded at room temperature. Upon excitation in the MLCT band $\left(\lambda_{\text {exc }}=532 \mathrm{~nm}\right)$, the transient absorption spectrum obtained resembles the characteristic triplet-triplet spectrum of [Zn(TPP)], first predicted by Gouterman ${ }^{52}$ and later reported by Holten and coworkers. ${ }^{53}$ Gouterman predicted two possible transitions from the porphyrin $\mathrm{T}_{1}$ state: an intense allowed transition that would result in a doubly excited configuration and consist of two absorption peaks to lower energy of the Soret band, and a weak, forbidden transition in the near infrared (IR) leading to a highly excited singlet configuration. In the transient absorption spectrum of $[\mathrm{Ru}(3)(4)]\left[\mathrm{PF}_{6}\right]_{2}$ (Fig. 12), the loss of the ground state porphyrin is clearly indicated by bleaching of the Soret band $(425 \mathrm{~nm})$ and of the $\mathrm{Q}(0,1)$ and $\mathrm{Q}(0,0)$ bands (560 and $600 \mathrm{~nm})$. The broad bands at 470 and $500 \mathrm{~nm}$ are associated with absorption of the porphyrin $\mathrm{T}_{1}$ state and creation of the doubly excited configuration. A broad absorption is present at lower energies, extending from $600 \mathrm{~nm}$ to the NIR, in agreement with the literature spectrum. ${ }^{33}$

The near-IR (NIR) transient absorption spectra of [Ru(3)(4)] $\left[\mathrm{PF}_{6}\right]_{2}$ are shown in Fig. 13. The band at $820 \mathrm{~nm}$ is associated with the forbidden, higher energy singlet which appears at
$832 \mathrm{~nm}$ for $[\mathrm{Zn}(\mathrm{TPP})]^{53}$ in $\mathrm{CH}_{2} \mathrm{Cl}_{2}$. For $[\mathrm{Ru}(3)(4)]\left[\mathrm{PF}_{6}\right]_{2}$, the NIR absorption was detected only in deaerated solution. The recovery of the ground state was monitored at 385, 425 and $470 \mathrm{~nm}$ for the aerated solution and at $385,425,470$ and $820 \mathrm{~nm}$ for the deaerated one. As expected for a triplet state, the lifetimes ranged from hundreds of nanoseconds for the aerated solution to tens of microseconds for the deaerated one, due to the exclusion of a non-radiative deactivation pathway through reaction with triplet $\mathrm{O}_{2}$. The decay curves are consistent with a mono-exponential decay in all cases; the lifetimes for ground state recovery are: $\tau_{385}=441 \pm 44 \mathrm{~ns}$ and $59 \pm 6 \mu \mathrm{s}, \tau_{425}=418 \pm$ $42 \mathrm{~ns}$ and $52 \pm 5 \mu \mathrm{s}, \tau_{470}=435 \pm 44 \mathrm{~ns}$ and $48 \pm 5 \mu \mathrm{s}, \tau_{820}=$ $49 \pm 5 \mu$ s. Since all the lifetimes are consistent within experimental error, it is reasonable to assume that all observed transitions originate from a single chemical species which we propose to be the porphyrin $\mathrm{T}_{1}$ state. Furthermore, we conclude that upon MLCT excitation a triplet-to-triplet energy transfer occurs from the ${ }^{3}$ MLCT level to T1, the latter being the lowest accessible level for $[\mathrm{Ru}(3)(4)]\left[\mathrm{PF}_{6}\right]_{2}$.

The literature contains a number of molecular triads and dyads related to $[\mathrm{Ru}(\mathbf{3})(\mathbf{4})]\left[\mathrm{PF}_{6}\right]_{2}$ (Scheme 3). ${ }^{54}$ When the triad (Scheme 3a) reported by Benniston et al..$^{55}$ is excited in the MLCT band, the ${ }^{3}$ MLCT emission is quenched in favour of a triplet-to-triplet energy transfer to the porphyrin $\mathrm{T}_{1}$ state. The lifetime of $\mathrm{T}_{1}$ was determined to be $65 \pm 5 \mu \mathrm{s}$ with a triplet-totriplet energy transfer rate constant of $8 \times 10^{10} \mathrm{~s}^{-1}$. A Dexter type mechanism of energy transfer ${ }^{56}$ was proposed, and it is significant that excitation into the $\mathrm{Q}$ band resulted in a decreased $\mathrm{S}_{1}$ fluorescence. Benniston et al. ${ }^{55}$ rationalize this in terms of singlet $\left(\mathrm{S}_{1}\right)$ to triplet $\left({ }^{3} \mathrm{MLCT}\right)$ energy transfer $(k=4 \times$ $10^{8} \mathrm{~s}^{-1}$ ), involving an endergonic Dexter type mechanism (a process that is spin-forbidden). In the osmium-containing dyad in Scheme $3 \mathrm{~b}$, excitation in the Soret band leads to direct transfer to the ${ }^{3}$ MLCT state ${ }^{57,58}$ followed by triplet-totriplet energy transfer to $\mathrm{T}_{1}$. A high rate constant for porphyrin fluorescence quenching again accounts for complete energy transfer. In oligopyridine complexes, the excited MLCT state is localized on one of the ligands, ${ }^{59}$ and Benniston et al.

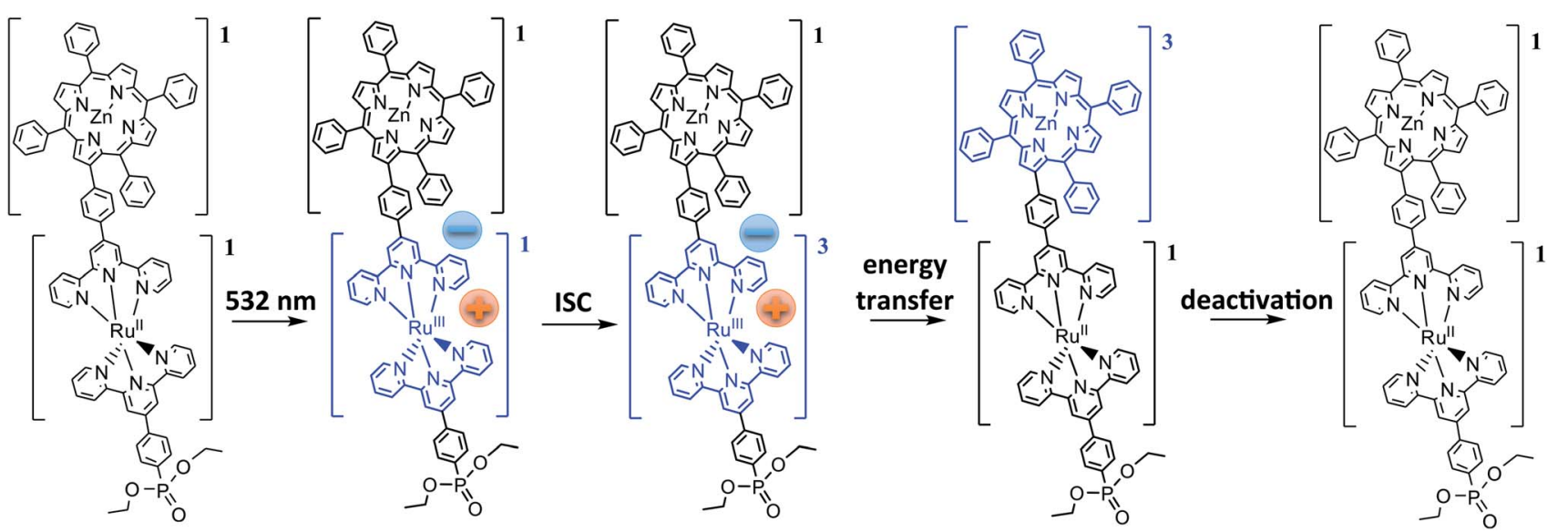

Scheme 4 Energy-transfer scheme upon ${ }^{1} \mathrm{MLCT}$ excitation at $532 \mathrm{~nm}$ in $[\mathrm{Ru}(3)(4)]\left[\mathrm{PF}_{6}\right]_{2}$. For the middle species in the scheme, the negative charge could be on either tpy domain. ISC = intersystem crossing. 
argue that the energy flows from $S_{1}$ to the tpy domain directly connected to the porphyrin. In addition, if the second tpy in the complex lacks an extended $\pi$-system in the 4 -position of the central pyridine ring, the electronic energy can be considered to reside on the porphyrin-bearing tpy because the intra-ligand energy transfer would not be as fast as that of energy transfer to the porphyrin triplet state. The overall effect is an intersystem crossing involving the porphyrin unit, involving the $\{\mathrm{Ru}(\mathrm{tpy})\}^{2+}$ domain. For the triad reported by Flamigni et al. (Scheme 3c), ${ }^{60}$ the energy transfer rate constant for the triplet-to-triplet transfer is $>5 \times 10^{10} \mathrm{~s}^{-1}$, consistent with a fast and quantitative quenching of the ruthenium-containing manifold. Once again the fluorescence originating from $S_{1}$ in quenched in favour of population of the ${ }^{3}$ MLCT.

Fig. 14 shows the relative energies of the tpy, MLCT and $\{\mathrm{Zn}(\mathrm{TPP})\}$ singlet and triplet states of $[\mathrm{Ru}(3)(4)]^{2+}$. The energy of the tpy domain was obtained by plotting the normalized absorption and emission spectra $\left(\lambda_{\text {exc }}=284\right.$ and $\left.310 \mathrm{~nm}\right)$ of $[\mathrm{Ru}(3)(4)]\left[\mathrm{PF}_{6}\right]_{2}$, expressed in wavenumbers and searching for a crossing point which corresponds to the $(0,0)$ transition. The values obtained were 345 and $353 \mathrm{~nm}$, corresponding to 3.59 and $3.51 \mathrm{eV}$. An average value of $3.55 \mathrm{eV}$ has been adopted for the tpy level. The $\{\mathrm{Zn}(\mathrm{TPP})\} \mathrm{S}_{2}$ level was obtained with the aforementioned procedure using spectra of 1 . A value of $427 \mathrm{~nm}$ $(2.90 \mathrm{eV})$ was obtained. The $\{\mathrm{Zn}(\mathrm{TPP})\} \mathrm{S}_{1}$ level was calculated from spectra of $[\mathrm{Ru}(3)(4)]\left[\mathrm{PF}_{6}\right]_{2}$, and searching for the crossing point between the $\mathrm{Q}(0,0)$ bands. This gave a value of $596 \mathrm{~nm}$ $(2.08 \mathrm{eV})$. The ${ }^{1}$ MLCT energy level was derived from the UV-Vis maximum of $[\mathrm{Ru}(3)(4)]\left[\mathrm{PF}_{6}\right]_{2}$, and the ${ }^{3} \mathrm{MLCT}$ level from the emission maximum of the analogous $\left[\mathrm{Ru}(\text { pytpy) })_{2}\right]\left[\mathrm{PF}_{6}\right]_{2}$ (pytpy $=4^{\prime}$-(4-pyridyl)-2,2' $: 6^{\prime}, 2^{\prime \prime}$-terpyridine) in MeCN (655 $\mathrm{nm},{ }^{61}$ $1.89 \mathrm{eV}$ ) since the ${ }^{3} \mathrm{MLCT}$ state of $[\mathrm{Ru}(3)(4)]\left[\mathrm{PF}_{6}\right]_{2}$ is not emissive at room temperature in solution. Finally, the $\{\mathrm{Zn}(\mathrm{TPP})\} \mathrm{T}_{1}$ energy $\left(770 \mathrm{~nm}^{62}\right.$ corresponding to $1.61 \mathrm{eV}$ ) was obtained from the literature data. The relative energies of the states allow us to propose the energy transfer process shown in Scheme 4. Upon ${ }^{1}$ MLCT excitation, fast intersystem crossing to ${ }^{3}$ MLCT occurs. Triplet-to-triplet energy transfer takes place with a rate constant $>2 \times 10^{10} \mathrm{~s}^{-1}$ (Fig. 14b), leading to the $\{\mathrm{Zn}(\mathrm{TPP})\} \mathrm{T}_{1}$ state. By deactivation of this state the ground state is recovered.

\section{Conclusions}

We have prepared and characterized the porphyrinfunctionalized tpy ligand 3, and its single crystal structure has been determined. The ruthenium(II) complex $[\mathrm{Ru}(3)(4)]\left[\mathrm{PF}_{6}\right]_{2}$ contains the peripheral light-harvesting domain in 3 coupled with a phosphonate ester functionality in $\mathbf{4}$ that allows the complex to be bound to nanoparticulate $\mathrm{TiO}_{2}$, the n-type semiconductor applied on the photoanode in DSCs. In solution, 3 and $[\mathrm{Ru}(3)(4)]\left[\mathrm{PF}_{6}\right]_{2}$ undergo two, reversible porphyrincentred oxidation processes at lower potential than the $\mathrm{Ru}^{2+}$ / $\mathrm{Ru}^{3+}$ couple in $[\mathrm{Ru}(3)(4)]\left[\mathrm{PF}_{6}\right]_{2}$. In the solution absorption spectra, the Soret and $\mathrm{Q}$ bands in $\mathbf{3}$ are little affected upon coordination to ruthenium(II) and detailed spectroelectrochemical studies of 3 and $[\mathrm{Ru}(3)(4)]\left[\mathrm{PF}_{6}\right]_{2}$ have been described. $\mathrm{FTO} / \mathrm{TiO}_{2}$ electrodes have been functionalized with
$[\mathrm{Ru}(3)(4)]^{2+}$ and solid-state absorption spectra demonstrate enhanced light absorption with respect to the standard DSC dye N719. However, the photoconversion efficiencies of dyesensitized solar cells (DSCs) sensitized with $[\mathrm{Ru}(3)(4)]^{2+}$ are disappointingly low. Transient absorption spectroscopic studies indicate that triplet-triplet energy transfer processes are the most likely reason for the poor DSC photoconversion efficiencies.

\section{Acknowledgements}

We acknowledge the Swiss National Science Foundation as part of the NCCR Molecular Systems Engineering, and the University of Basel for financial support. The SNF R'Equip program is acknowledged for grant number 206021_157687/1. Nathalie Marinakis and Sarah Keller are thanked for providing ligand 4 and recording NMR spectra, respectively.

\section{Notes and references}

1 B. O'Regan and M. Grätzel, Nature, 1991, 353, 737.

2 M. Grätzel, Acc. Chem. Res., 2009, 42, 1788; M. Grätzel, Inorg. Chem., 2005, 44, 6841; M. Grätzel, J. Photochem. Photobiol., C, 2003, 4, 145 and references therein.

3 Dye Sensitized Solar Cells, ed. K. Kalyanasundaram, CRC Press, Boca Raton, 2010.

4 T. Higashino and H. Imahori, Dalton Trans., 2015, 44, 448.

5 A. Hagfeldt, G. Boschloo, L. Sun, L. Kloo and H. Pettersson, Chem. Rev., 2010, 110, 6595.

6 A. Hagfeldt and M. Grätzel, Acc. Chem. Res., 2000, 33, 269.

7 Y. Xie, Y. Tang, W. Wu, Y. Wang, J. Liu, X. Li, H. Tian and W.-H. Zhu, J. Am. Chem. Soc., 2015, 137, 14055.

8 A. Hagfeldt, G. Boschloo, L. Sun, L. Kloo and H. Pettersson, Chem. Rev., 2010, 110, 6595.

9 A. Mishra, M. Fischer and P. Bäuerle, Angew. Chem., Int. Ed., 2009, 48, 2474.

10 A. Yella, H.-W. Lee, H. N. Tsao, C. Yi, A. K. Chandiran, M. K. Nazeeruddin, E. W.-G. Diau, C.-Y. Yeh, S. M. Zakeeruddin and M. Grätzel, Science, 2011, 334, 629.

11 C.-Y. Chen, M. Wang, J.-Y. Li, N. Pootrakulchote, L. Alibabaei, C.-h. Ngoc-le, J.-D. Decoppet, J.-H. Tsai, C. Grätzel, C.-G. Wu, S. M. Zakeeruddin and M. Grätzel, ACS Nano, 2009, 3, 3103.

12 H. Ozawa, Y. Okuyama and H. Arakawa, ChemPhysChem, 2014, 15, 1201.

13 K. Kakiage, Y. Aoyama, T. Yano, T. Otsuka, T. Kyomen, M. Unno and M. Hanaya, Chem. Commun., 2014, 50, 6379.

14 S. Mathew, A. Yella, P. Gao, R. Humphry-Baker, B. F. E. Curchod, N. Ashari-Astani, I. Tavernelli, U. Rothlisberger, M. K. Nazeeruddin and M. Grätzel, Nat. Chem., 2014, 6, 242.

15 K. Kakiage, Y. Aoyama, T. Yano, K. Oya, T. Kyomen and M. Hanaya, Chem. Commun., 2015, 51, 6315.

16 Z. Yao, M. Zhang, H. Wu, L. Yang, R. Li and P. Wang, J. Am. Chem. Soc., 2015, 137, 3799.

17 M. K. Panda, K. Ladomenou and A. G. Coutsolelos, Coord. Chem. Rev., 2012, 256, 2601. 
18 W. M. Campbell, A. K. Burrell, D. L. Officer and K. W. Jolley, Coord. Chem. Rev., 2004, 248, 1363.

19 M. Urbani, M. Grätzel, M. K. Nazeeruddin and T. Torres, Chem. Rev., 2014, 114, 12330.

20 C. Stangel, K. Ladomenou, G. Charalambidis, M. K. Panda, T. Lazarides and A. G. Coutsolelos, Eur. J. Inorg. Chem., 2013, 1275.

21 I. Jung, H. Choi, J. K. Lee, K. H. Song, S. O. Kang and J. Ko, Inorg. Chim. Acta, 2007, 360, 3518.

22 A. L. A. Parussulo, B. A. Iglesias, H. E. Toma and K. Araki, Chem. Commun., 2012, 48, 6939.

23 M. Schwalbe, P. Wrzolek, G. Lal and B. Braun, Eur. J. Inorg. Chem., 2014, 4209; M. Schwalbe, R. Metzinger and T. S. Teets, Chem.-Eur. J., 2012, 18, 15449; C. Monnereau, J. Gomez, E. Blart, F. Odobel, S. Wallin, A. Fallberg and L. Hammarström, Inorg. Chem., 2005, 44, 4806.

24 G.-Y. Gao, J. V. Ruppel, D. B. Allen, Y. Chen and X. P. Zhang, J. Org. Chem., 2007, 8, 9060.

25 S. A. Vail, D. I. Schuster, D. M. Guldi, M. Isosomppi, N. Tkachenko, H. Lemmetyinen, A. Palkar, L. Echegoyen, X. Chen and J. Z. H. Zhang, J. Phys. Chem. B, 2006, 110, 14155.

26 H. S. Mehr, N. C. Romano, R. Altamimi, J. M. Modarelli and D. A. Modarelli, Dalton Trans., 2015, 44, 3176.

27 V. Spampinato, N. Tuccitto, S. Quici, V. Calabrese, G. Marletta, A. Torrisi and A. Licciardello, Langmuir, 2010, 26, 8400 .

28 APEX2, version 2 User Manual, Bruker Analytical X-ray Systems, Inc., M86-E01078, Madison, WI, 2006.

29 P. W. Betteridge, J. R. Carruthers, R. I. Cooper, K. Prout and D. J. Watkin, J. Appl. Crystallogr., 2003, 36, 1487.

30 I. J. Bruno, J. C. Cole, P. R. Edgington, M. K. Kessler, C. F. Macrae, P. McCabe, J. Pearson and R. Taylor, Acta Crystallogr., Sect. B: Struct. Sci., 2002, 58, 389.

31 C. F. Macrae, I. J. Bruno, J. A. Chisholm, P. R. Edgington, P. McCabe, E. Pidcock, L. Rodriguez-Monge, R. Taylor, J. van de Streek and P. A. Wood, J. Appl. Crystallogr., 2008, 41, 466.

32 H. J. Snaith, Energy Environ. Sci., 2012, 5, 6513.

33 H. J. Snaith, Nat. Photonics, 2012, 6, 337.

34 See for example: A. K. D. Dime, C. H. Devillers, H. Cattey, B. Habermeyer and D. Lucas, Dalton Trans., 2012, 41, 929; R. K. Kumar, A. Goldborth and I. Goldberg, Z. Kristallogr., 1997, 212, 383; M. P. Bryn, C. J. Curtis, Yu. Hsiou, S. I. Khan, P. A. Sawin, S. K. Tendick, A. Terzis and C. E. Strouse, J. Am. Chem. Soc., 1993, 115, 9480; L. C. Gilday, N. G. White and P. D. Beer, Dalton Trans., 2012, 41, 7092.

35 See for example: W. R. Scheidt and Y. J. Lee, Struct. Bonding, 1987, 64, 1.

36 S. M. Zakeeruddin, M. K. Nazeeruddin, P. Pechy, F. P. Rotzinger, R. Humphry-Baker, K. Kalyanasundaram and M. Grätzel, Inorg. Chem., 1997, 36, 5937.
37 D. K. Zhong, S. Zhao, D. E. Polyansky and E. Fujita, J. Catal., 2013, 307, 140.

38 E. C. Constable, C. E. Housecroft, M. Šmídková and J. A. Zampese, Can. J. Chem., 2014, 92, 724.

39 N. Armaroli, F. Diederich, L. Echegoyen, T. Habicher, L. Flamigni, G. Marconi and J.-F. Nierengarten, New J. Chem., 1999, 77.

40 E. C. Constable, A. M. W. Cargill Thompson, D. A. Tocher and M. A. M. Daniels, New J. Chem., 1992, 16, 855.

41 A. Harriman, J. Chem. Soc., Faraday Trans. 1, 1980, 76, 1978. 42 A. Juris, V. Balzani, F. Barigelletti, S. Campagna, P. Belser and A. von Zelewsky, Coord. Chem. Rev., 1988, 84, 85.

43 A. Klein, in Spectroelectrochemistry, ed. W. Kaim and A. Klein, Royal Society of Chemistry, Cambridge, 2008, ch. 4, p. 91.

44 J. Pawlik, L. Gherghel, S. Karabunarliev and M. Baumgarten, Chem. Phys., 1997, 221, 121.

45 L. Zhang and J. M. Cole, ACS Appl. Mater. Interfaces, 2015, 7, 3427.

46 F. J. Malzner, S. Y. Brauchli, E. Schönhofer, E. C. Constable and C. E. Housecroft, Polyhedron, 2014, 82, 116.

47 G. Guerrero, P. H. Mutin and A. Vioux, Chem. Mater., 2001, 13, 4367.

48 G. Guerrero, P. H. Mutin, E. Framery and A. Vioux, New J. Chem., 2008, 32, 1519.

49 A. Vioux, J. Le Bideau, P. H. Mutin and D. Leclercq, Top. Curr. Chem., 2004, 232, 145.

50 M. Kasha, Discuss. Faraday Soc., 1950, 9, 14.

51 A. Lukaszewicz, J. Karolczak, D. Kowalska, A. Maciejewski, M. Ziolek and R. P. Steer, Chem. Phys., 2007, 331, 359.

52 M. Gouterman, J. Chem. Phys., 1960, 33, 1523.

53 J. Rodriguez, C. Kirmaier and D. Holten, J. Am. Chem. Soc., 1989, 111, 6500.

54 P. K. Poddutoori, P. Poddutoori and B. G. Maya, J. Porphyrins Phthalocyanines, 2006, 10, 1049.

55 A. C. Benniston, A. Harriman, C. Pariani and C. A. Sams, Phys. Chem. Chem. Phys., 2006, 8, 2051.

56 D. L. Dexter, J. Chem. Phys., 1953, 21, 836.

57 A. C. Benniston, A. Harriman, C. Pariani and C. A. Sams, J. Phys. Chem. A, 2007, 111, 8918.

58 A. C. Benniston and A. Harriman, Coord. Chem. Rev., 2008, 252, 2528.

59 P. G. Bradley, N. Kress, B. A. Hornberger, R. F. Dallinger and W. H. Woodruff, J. Am. Chem. Soc., 1981, 103, 7441.

60 L. Flamigni, F. Barigelletti, N. Armaroli, B. Ventura, J.-P. Collin, J.-P. Sauvage and J. A. G. Williams, Inorg. Chem., 1999, 38, 661.

61 E. C. Constable, C. E. Housecroft, A. Cargill Thompson, P. Passaniti, S. Silvi, M. Maestri and A. Credi, Inorg. Chim. Acta, 2007, 360, 1102.

62 V. A. Waiters, J. C. de Paula, B. Jackson, C. Nutaitis, K. Hall, J. Lind, K. Cardozo, K. Chandran, D. Raible and C. M. Phillips, J. Phys. Chem., 1995, 99, 1166. 